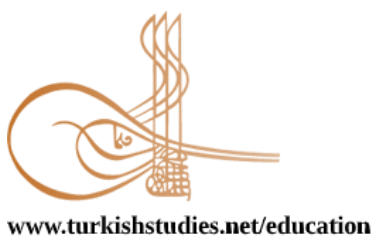

Turkish Studies - Educational Sciences

\title{
Yabancı Dil Olarak Türkçe Öğretiminde Türkçe ve İngilizce Öğretmeni Adaylarının Öz Yeterlilik Algıları
}

\author{
Self-Efficacy Perceptions of Turkish and English Prospective Teachers in Teaching Turkish as a \\ Foreign Language
}

\author{
Ümit Yıldız - Halide İbiloğlu** - Gözde Sarığlu***
}

\begin{abstract}
The purpose of this study is to determine the self-efficacy perceptions of prospective teachers studying Turkish and English teaching undergraduate programs towards the qualifications an instructor, who will work in the field of teaching Turkish as a foreign language, should have, the field information and knowledge of teaching methods in this field. In this study, the focus group interview technique was used. A semi-structured interview form developed by the researchers was used in the focus group interviews. The study group consisted of $263^{\text {rd }}$ and $4^{\text {th }}$-grade prospective teachers studying in the Departments of Turkish and English Language Teaching at a state university in southern Turkey during the 2018-2019 academic year. The data were analysed by using the content analysis technique. According to the results, it was seen that there was a consensus among the participants regarding the qualifications an instructor who is working/will work in the field of teaching Turkish as a foreign language should have. All the participants stated that the instructors should have the mastery of field knowledge, be competent in teaching methods both in theory and practice and know a mediating language. It was also found that in terms of managing teaching Turkish as a foreign language processes, the prospective Turkish teachers felt insufficiency in language teaching methods while the prospective English teachers considered themselves as inadequate in the field knowledge of Turkish. The participants stated that the teaching hours allocated to teaching Turkish as a foreign language should be increased and there should be more emphasis on practical courses for these processes. Moreover, since teaching Turkish as a foreign language is a separate specialisation, opening an undergraduate program for this field will bring a long-term solution to the problems in this field.
\end{abstract}

Structured Abstract: Introduction: In the rapidly globalizing world, communication traffic has increased with the positive momentum gained by the dizzying developments in the fields of technology and communication. In this context, the need to know and use each other's language of communication for societies

\footnotetext{
* Doç. Dr. Türkçe Eğitimi, MEB

Assoc. Prof. Dr., Turkish Education, Ministry of National Education

ORCID 0000-0003-0415-8051

umityildiztr@gmail.com

*** Yüksek Lisans Öğrencisi, Akdeniz Üniversitesi,Eğitim Fakültesi, Türkçe Eğitimi Bölümü

Graduate Student, Akdeniz Universty, Educational Faculty, Turkush Education Department

ORCID 0000-0002-2108-7964

halidealak1984@hotmail.com

**** Yüksek Lisans Öğrencisi, Akdeniz Üniversitesi,Eğitim Fakültesi, Türkçe Eğitimi Bölümü

Graduate Student, Akdeniz Universty, Educational Faculty, Turklsh Education Department

ORCID 0000-0001-7960-2431

gozdekaradayii@gmail.com

Cite as/ Atıf: Yıldız, Ü., İbiloğlu, H. \& Sarığlu, G. (2020). Yabancı dil olarak Türkçe öğretiminde Türkçe ve İngilizce öğretmeni adaylarının öz yeterlilik algıları. Turkish Studies - Education, 15(4), 3047-3070. https://dx.doi.org/10.47423/TurkishStudies. 43345

Received/Geliş: 04 May/Mayıs 2020

Accepted/Kabul: 27 August/Ağustos 2020

Copyright (C) INTAC LTD, Turkey

Checked by plagiarism software

Published/Yayın: 30 August/Ağustos 2020

CC BY-NC 4.0
} 
that are getting closer has started to feel more important than ever before. The phenomenon of knowing and using a foreign/second language, which was defined as a personal development area in the past, has become the prerequisite for success and employment in many areas today. As in other languages, the need and demand for knowing, speaking and teaching Turkish as a foreign language has gained an upward momentum in the last 30 years and has shown an upward trend without slowing down. This increasing interest in the field of teaching Turkish as a foreign language necessitated the revision of the educational activities in this field and some updates. Advanced and established educational activities in similar disciplines have not reached the same level in the field of teaching Turkish as a foreign language. While conducting new studies in this field, first of all, it has been focused on studies on the qualifications of trainers carrying out educational activities. Considering the relevant literature, there are some different opinions about who should be the trainers working in this context, there is no clear chart or document about what qualifications they should have, and the trainers in the field of English and Turkish see themselves as ideal to carry out this task. In this study, the opinions of the teacher candidates in the fields of English and Turkish Education on this subject were consulted, and solutions were tried to be offered to these issues.

Purpose: The purpose of this study is to determine the self-efficacy perceptions of prospective teachers studying Turkish and English teaching undergraduate programs towards the qualifications an instructor, who will work in the field of teaching Turkish as a foreign language, should have, the field information and knowledge of teaching methods in this field.

Method: This study, which was carried out to determine the self-efficacy perceptions of the prospective teachers in teaching Turkish as a foreign language, was prepared under the phenomenology pattern, one of the qualitative research designs. The study group consists of 26 teacher candidates $(13=$ Turkish, $13=$ English) who continue their education in the 3rd and 4th grades of Turkish and English Language Teaching Departments of a state university in the spring semester of the 2018-2019 academic year. Participants were determined using the convenience sampling technique, one of the purposeful sampling methods. The basic criterion in determining the participants was determined as "to take the compulsory, compulsory elective and elective courses in the field of teaching Turkish to foreigners in Turkish and English language education undergraduate programs". The data were collected through an interview form consisting of 7 semi-structured questions prepared by the researchers. During the data collection process, the focus group interview (FGI) technique was used. After the interviews were completed, the audio recordings were transcribed electronically and the analysis process started. The content analysis technique was used to analyse the data.

Results: As a result of examining the data collected from the pre-service teachers, it was determined that the prospective teachers positioned the dominance of Turkish culture and the culture of the target audience where Turkish will be taught, in the context of the qualifications that should be found in the instructor who will take part in the processes. In the context of the qualifications that should be available to the instructor who will take part in the processes of TAFL (Turkish as a Foreign Language), the competence to have knowledge and application skills within the framework of foreign language teaching methods and to have a command of Turkish content knowledge ranks second. It was observed that Turkish and English prospective teachers generally listed the qualifications that should be found in the instructors who will take part in the processes of TAFL, as having a command of Turkish culture and the culture of the target audience, a command of Turkish content knowledge, knowledge and application skills in the context of foreign language teaching methods and cultural dominance. While the prospective Turkish teachers emphasized their knowledge of field knowledge in the first place in terms of the qualifications that should be present in the instructor who will take part in the processes of TAFL, it was determined that the prospective English teachers thought it was more important to know the culture of the target audience. It is seen that the prospective Turkish and English teachers agree that the instructors who will take part in the processes of TAFL should be graduates of the English and Turkish teaching undergraduate program. However, the prospective Turkish teachers stated that they felt inadequate in terms of knowledge and application skills required for foreign language teaching. On the other hand, research results reveal that the prospective English teachers feel competent in terms of knowledge and application skills of foreign language teaching methods, and insufficient in terms of Turkish content knowledge. On the other hand, it is seen that all of the prospective Turkish and English teachers agree to open an independent undergraduate program that will train the instructors who will take part in the processes of TAFL. When the findings of the effect of knowing a foreign language on TAFL processes are examined, all of the participants agree that the instructor working abroad should know a mediating language. On the other hand, the prospective Turkish teachers generally think that foreign/mediating language should not be used during the lessons in

Turkish Studies - Education, 15(4) 
Turkish teaching processes. It is seen that the prospective English teachers agree that using a foreign/mediating language at a basic level (A1, A2) can be beneficial in teaching Turkish as a foreign language. According to the research results; the prospective Turkish teachers stated that they do not feel competent in terms of knowledge and application skills in foreign language teaching methods in the processes of TAFL. On the other hand, the prospective English teachers state that they feel competent in terms of knowledge and application skills in foreign language teaching methods in general, by referring to the education they received in their undergraduate program. In the context of the findings related to language skills, which they think will have the most difficulty in the processes of TAFL, the areas in which the third-grade prospective teachers in the Turkish language teaching undergraduate program will have the most difficulties; teaching grammar, speaking, listening and writing skills. The 4th-grade prospective teachers of the Turkish language teaching undergraduate program have listed the areas they think will have the most difficulty in the processes of TAFL, as speaking, writing and grammar teaching. On the other hand, the most difficult areas of the third-grade prospective teachers in the undergraduate program of English Language Teaching in their TAFL processes; It is seen that they have listed as teaching grammar and writing skills. The 4th-grade prospective teachers of the undergraduate program of English language teaching have listed the areas they will have the most difficulties in the processes of TAFL as teaching writing, speaking and listening skills. It is observed that although the prospective Turkish teachers feel competent in managing their mother tongue teaching/training processes, they do not have the same level of competence in teaching Turkish to foreigners. In this context, it can be said that the courses for TAFL, which takes place in only two semesters in undergraduate programs, are inadequate in terms of course hours, content and diversity in providing prospective teachers with the necessary competence in terms of knowledge and application skills in the context of teaching Turkish to foreigners.

Keywords: Teaching Turkish to Foreigners, Turkish as a Foreign Language, Turkish and English Prospective Teachers, Self-efficacy, Teacher Competencies.

Öz: Bu araştırmanın amacı, Türkçe ve İngilizce öğretmenliği lisans programlarında öğrenim gören öğretmen adaylarının yabancı dil olarak Türkçe öğretimi (YDTÖ) alanında çalışacak eğiticide bulunması gereken niteliklere, yabancı dil olarak Türkçe öğretiminde alan bilgisine, öğretim yöntemleri bilgi ve becerisi boyutlarına yönelik öz yeterlilik algılarının belirlenmesidir. Bu nitel araştırmada odak grup görüşmesi (OGG) tekniğine başvurulmuştur. Odak grup görüşmesi yoluyla veri toplama sürecinde, araştırmacılar tarafından geliştirilen yarı yapılandırılmış görüşme formu kullanılmıştır. Araştırmanın çalışma grubunu, 2018-2019 eğitim öğretim yılında Türkiye'de Akdeniz Bölgesinde bir devlet üniversitesinde Eğitim Fakültesi Türkçe ve İngilizce öğretmenliği lisans programlarının 3. ve 4. sınıflarında öğrenim gören 26 öğretmen adayı oluşturmaktadır. Elde edilen veriler, içerik çözümlemesi tekniğiyle incelenmiş ve sınıflandırılmıştır. Araştırma sonuçlarına göre, katılımcıların genel olarak YDTÖ süreçlerinde görev alan/alacak eğiticinin Türkçe alan bilgisine hâkim olması, öğretim yöntemleri bağlamında bilgi ve uygulama boyutunda yetkin olması ve bir araç dil bilmesi gerektiği konusunda fikir birliği içinde oldukları görülmüştür. YDTÖ süreçlerini yönetme boyutunda ise Türkçe öğretmeni adaylarının dil öğretim yöntemleri, İngilizce öğretmeni adaylarının ise Türkçe alan bilgisi bağlamında kendilerini yetersiz hissettikleri görülmektedir. Katılımcılar, genel olarak eğitim aldıkları programlarda YDTÖ süreçlerine ayrılan ders saatlerinin arttırılması ve YDTÖ süreçleri için uygulama derslerine ağırlık verilmesi gerektiğini ifade etmişlerdir. Diğer taraftan, YDTÖ’ nün ayrı bir ihtisas alanı olması nedeniyle bu alanda lisans programı açılmasının, YDTÖ süreçlerinde karşılaşılan sorunlara uzun vadeli çözüm olacağını vurgulamışlardır.

Anahtar Kelimeler: Yabancılara Türkçe Öğretimi, Yabancı Dil Olarak Türkçe, Türkçe ve İngilizce Öğretmeni Adayları, Öz Yeterlilik, Öğretmen Yeterlilikleri.

\section{Giriş}

Hızla küreselleşen dünyada, başta teknoloji ve iletişim alanlarındaki baş döndürücü gelişmelerin kazandırdığı pozitif ivmeyle toplumlar ve ülkelerarası ilişki ile iletişim trafiği artmıştır. $\mathrm{Bu}$ bağlamda, yakınlaşan toplumların, birbirlerinin iletişim dilini bilme ve kullanma ihtiyacı daha önce hiç olmadığı kadar önemini hissettirmeye başlamıştır. Geçmişte kişisel gelişim alanı olarak tanımlanan yabancı/ikinci bir dili bilme ve işlevsel kullanabilme olgusu, günümüzde birçok alanda 
başarının, işe girmenin önkoşulu haline gelmiştir. Diğer dillerde olduğu gibi, Türkçenin yabancı dil olarak bilinmesi, konuşulması ve öğretimine olan ihtiyaç ve talep son 30 yılda yukarı doğru bir ivme kazanmış olup hız kesmeden yükselme eğilimi göstermiştir.

Son yıllarda, Türkiye'nin diğer ülkelerle siyasi ve ekonomik ilişkilerinin gelişmesi, eğitim, sağlık gibi nedenlerle Türkiye'ye yapılan göçlerin çoğalması, Türkçenin yabancı dil olarak daha fazla talep görmesinde önemli etken olmuştur (Yıldız, 2018). Bu etkenler, ülkemizde yabancı dil olarak Türkçe öğretiminin önemini artırmıştır. Bu durum, yabancı dil olarak Türkçe öğrenen kitlenin artmasına katkı sağlamıştır. Ülkeler arası iyi ilişkilerin bu seviyede sürdürülebilmesi ve daha iyi yerlere gelebilmesi ülkemizin diğer ülkelerce doğru anlaşılması ve doğru tanınabilmesi, dil öğretilen kitleye dilimizin, dolayısıyla bizi yansıtan kültürümüzün doğru aktarılmasıyla mümkündür. Bu nedenle, YDTÖ ortamlarının, YDTÖ'de kullanılan ders kitaplarının ve programın, özellikle eğitim süreçlerinin en önemli öznesi sayılabilecek öğretmenlerin nitelikli ve donanımlı olması önem arz etmektedir. Eğitim alanında, hedefe ulaşmak için birçok araç-gereç ve materyal kullanılsa da hiçbiri eğitici kadar etkili olmamaktadır (Çiftci, 2011). Öğretmenler, özellikle yabancı dil öğretmenleri, öğretim süreçlerinin önemli bir unsurunu oluştururken süreç içinde önemli sorumluluklar taşımaktadırlar (Saygılı ve Kana, 2018). Bu sorumluluklar dil öğretim sürecinin tamamına yayılan kapsamlı bir rol sahipliğidir (Archana ve Usha, 2017). Eğiticilerin üstlendiği bu roller, 'eğitici rolü, kolaylaştırıcı/öğreten rolü, bilirkişi/değer biçen rolü, yönetici rolü, değerlendirici rolü’ şeklinde farklılaşabilmektedir. Bu bağlamda, Türkçenin ana dili ve yabancı dil olarak öğretimi; alan bilgisi, yabancı dil öğretim yöntemleri bilgi ve uygulama becerisi boyutlarıyla birbirinden farklı süreçleri içerdiğinden, süreçlerde görev alacak eğiticiler açısından da farklı donanımlara sahip olmayı gerektirmektedir. Bir dili bilmenin ve o dili öğretme işinin birbirinden farklı olduğu gerçeği akademik araştırmalarda sık sık dile getirilmektedir (Güler, 2012).

Bu nedenle, Türkçenin yabancı dil olarak öğretiminde görev alacak eğiticilerin Türkçeyi ana dili olarak konuşuyor olmalarının yanı sıra bu alanda eğitim almaları ve uzmanlaşmaları gerekmektedir. Nitekim yabancı dil olarak Türkçe öğretimini diğer dillerle karş1laştırdığımızda diğer dillere nazaran hâlihazırda aynı seviye olmadığına yönelik durumlar ortaya çıkmaktadır. Lingua franca (ortak dil) olarak görülen İngilizcenin, Latin toplumlarında ve Amerika'da yaygın olarak konuşulan İspanyolcanın, Avrupa'nın resmî dillerinden biri olarak kabul edilen Almancanın, ticaret devinin dili olan Çincenin ve önde gelen diğer dillerden bazıları olan Fransızca ve İtalyancanın yabancı dil öğretimi konusunda kazandığı ivme, sahip olduğu tecrübe ve kullandığı öğretim teknikleri açısından yabancı dil olarak Türkçe öğretimi henüz diğer paydaşlarıyla aynı seviyeye ulaşamamıştır. Yabancı/ikinci dil olarak Türkçe öğretiminde görev alacak eğitimcileri yetiştirecek lisans programlarının hâlâ açılamamış olmasının da bunda payı olduğu söylenebilir. Sistematik ve kapsamlı bir süreci içinde barındıran bu öğretim ortamlarını yönlendirecek eğiticilerin eğitiminin bir lisans düzeyi boyutunda gerçekleştirilememiş olması, bu süreçte görev alacak eğiticilerin hangi alanlardan olması gerektiği yönünde bir belirsizliğe neden olmaktadır. Diğer taraftan, adı geçen dillerin, özellikle İngilizcenin, yabancı ve ikinci dil olarak öğretimi tarihinin çok daha eskiye dayandığ bir gerçektir. Bu nedenle, bu dil/dillerin yabanci/ikinci dil olarak öğretiminin, zaman içinde ilgili lisans, lisansüstü programlarının açıldığı, eğitim yönetimlerinin geliştiği, öğretim materyallerinin tasarlandığı ve tüm boyutlarıyla sistematik bir temele oturtulduğu görülmektedir. Türkçenin yabancılara öğretimi alanına dönük benzer bir kronolojik sürecin işlemesinin günümüzdeki en pratik karşıllı̆ı, ilk adım olarak, alana özgü öğretmen yetiştirecek lisans programlarının açılarak alanın ayrı, kendi metodolojisi ve dinamikleri olan bir disiplin olduğunun kabul edilmesidir. Bu bağlamda, ilk kabul edilmesi gereken gerçek, ana dili ile yabancı dil öğretiminin başlı başına ayrı iki disiplin olduğudur. Dolayısıyla, üzerinde durulması gereken bir diğer nokta ise yabancı dil öğretimi sertifika programlarıyla alana dönük metodolojik olarak güçlendirilmiş ana dili öğretmenleriyle yabancı dil olarak Türkçe öğretiminin geleceğinde arzu edilen düzeyin yakalanamayacağıdır. Mevcut işleyiş̧e bakıldığında, Türkçeyi ana dili olarak 
öğreten/öğretecek öğretmenlere yönelik Türkçe öğretmeni özel alan yeterlilikleri (MEB, 2008) belirlenmiş olmasına rağmen, Türkçenin yabancı dil olarak öğretimi alanına yönelik tüm paydaşların üzerinde mutabık kaldığı resmî bir özel alan yeterlilikleri çerçevesi henüz oluşturulmamıştır. Bu durum, Türkçenin yabancı dil olarak öğretiminin gelişimini ve yayılımını olumsuz bir şekilde etkilemesine sebep olmaktadır. Özellikle alana özgü belirli bir lisans programının açılmasının ve bu alanda çalışacak eğiticilerin yeterliliklerinin ayrıntılı bir şekilde belirtilmesinin, Türkçenin yabancı dil olarak öğretimi alanının önümüzdeki yıllarda çok daha iyi yerlere gelmesinde etkili olacağı söylenebilir.

İlgili literatür incelendiğinde, yabancı dil olarak Türkçe öğreten öğretmenlerin özel alan yeterliliklerinin neler olması gerektiğine yönelik birtakım araştırmalar yapıldığı görülmektedir. Ancak alanda bu konuda yapılmış yayınların nicelik açısından oldukça sınırlı olduğu tespit edilmiştir. Yapılan araştırmalara bakıldığında, Mete'nin (2012b) "Türkçeyi yabancı dil olarak öğreten öğretmenlerin özel alan yeterlilikleri üzerine bir araştırma" isimli doktora tez çalışması ile bu bağlamda bir "Özel Alan Yeterlilikleri Taslağı" ortaya koyduğu görülmektedir. "Yabancı dil olarak Türkçe öğretiminde öğretmen yeterlilikleri üzerine bir çalışma" isimli makalede ise Yıldız ve Tepeli (2014) yabancı dil olarak Türkçe öğretecek eğiticilerde bulunması gereken öğretmen yeterliliklerini "konu alanına/alan bilgisine yönelik yeterlilikler, öğrenme-öğretme sürecine/öğretmenlik mesleğine yönelik yeterlilikler, program ve içerik bilgisine yönelik yeterlilikler, yabancı dil olarak Türkçe öğretimi süreçlerinde öğrenme gelişimini izleme ve değerlendirme becerilerine yönelik yeterlilikler" şeklinde dört başlıkta altında incelemiştir. Diğer taraftan, Barın, Çangal ve Başar (2017) "Yabancı dil olarak Türkçe öğretmeninin özel alan yeterliliklerini" belirlemeye yönelik yürüttükleri bir araştırma ile 'Yabancılara Türkçe Öğretimi Süreçlerini Planlama ve Hazırlama, Dil Becerilerini Geliştirme, Dil Gelişimini İzleme ve Değerlendirme, Kurum, Kuruluş ve Kişilerle Işs Birliği İçerisinde Çalışma ve Yabancılara Türkçe Öğretimi Alanında Mesleki Gelişimini Sağlama' olmak üzere toplamda beş yeterlilik alanından oluşan bir öneride bulunmuşlardır. Barın, Çangal ve Başar (2017) da benzer şekilde yabancılara Türkçe öğretimi alanında çalışacak öğretmenlerin yeterliliklerin belirlenmesine yönelik devlet eliyle gerçekleştirilecek resmi çalışmalara da ihtiyaç duyulduğu gerçeğine vurgu yapmaktadır. Diğer taraftan, Yabancılara Türkçe öğretimi alan paydaşlarının, çalışan tecrübeli akademisyenler, ilgili kurum ve kuruluşların temsilcileri gibi, katılımıyla öğretmenlerin özel alan yeterliliklerini belirlemesi gerekliliğine dikkat çekmektedir. Filiz ve Mete (2013), yürüttükleri araştırmada yabancılara Türkçe öğretimi konusunda alan öğretmenlerinin ve akademisyenlerin görüşlerine başvurmuş, araştırma sonucunda yabancı dil olarak Türkçe öğretimi alanında görev alacak eğiticilerde olması gereken özellikleri mesleki bilgi, mesleki beceri ve mesleki tutum ve değerler başlıkları altında kategorileştirmiştir. Buna göre, alan öğretmenleri ve akademisyenlerin mesleki bilgi kategorisinde en çok vurguladıkları özellik dil öğretim yöntem, yaklaşım ve tekniklerini uygulayabilme yeterliliği olmuştur. Mesleki beceri kategorisinde ise en çok alt1 çizilen özellik dil öğretim ortamlarını düzenleyebilme olmuştur. Mesleki tutum ve değerler kategorisine bakıldığında ise dil-kültür etkileşimine duyarlı olabilme olmuştur.

Uluslararası literatüre baktığımızda ise bir dilin yabancı/ikinci dil olarak öğretimi alanında çalışacak eğiticilerin hangi özelliklerinin ve yeterliliklerinin olması gerektiğine yönelik çeşitli araştırmalar yürütüldüğü görülmektedir. Richards (2010) tarafindan yapılan araştırmada, bu alanda çalışan/çalışacak eğiticilerde dil temelli yeterliliklerin önemli bir faktör olduğu ve sürecin başarıyla tamamlanabilmesi için eğiticilerin öğretilen dile hâkim, dili kullanma konusunda iyi bir model, sinıf içi öğretim dilinin öğrencilere uyarlanması konusunda üstün yeterliliğe sahip olması gerektiği vurgulanmıştır. Buna ek olarak, dilin kültür aktarımı rolüne atıf yapılarak eğiticilerin öğrettikleri dilin kültürü, tarihi, özellikleri ve süreci hakkında bilgi düzeyinin iyi olması gerektiği de belirtilmiş̧ir. Brosh (1996) da etkili ve iyi yabancı dil öğretmenin özelliklerini gruplandırmıştır. Bu sinıflamaya göre, yabanc1 dil öğretmenleri öğrettiği dile hâkim, öğrencilerde ilgili, merak ve motivasyon arttırıcı şeklinde süreci yöneten ve açıklama yapan, öğrencilere karşı ön yargısı olmayan 
ve öğrencilerin ihtiyaç duyduğu zamanlarda onlara yardımcı olan bireylerdir. Diğer dillerin yabancı dil/ikinci dil olarak öğretimi konusunda öne çıkan ana dil konuşuru olup olmama durumu ise Türkçenin yabancı dil olarak öğretimi alanında karşımıza çıkan sorunlardan birisi değildir. Farklı alanlardan mezun olan bireylerin bu alanda çalışabilmesine rağmen, bütün eğiticilerin ana dillerinin Türkçe olması eğitim öğretim sürecinde hedef dilin özelliklerini kavrayan, artikülasyon özelliklerine hâkim, toplumdaki kültürünü benimseyen eğiticilerin eğitim öğretim sürecinde yer almasına katkıda bulunmaktadır. Brog (2006) ise yapmış olduğu araştırmada, ana dil konuşuru olup olmama durumunun yabancı dil öğretmenlerinin özellikleri arasında ayırt edici bir rolü olduğu sonucuna ulaşmıştır. Cho (2006) da dil yeterliliğine vurgu yaparak, öğretmenlerin mesleki yeterliliklerinde başta hedef dile ait bilgi olmak üzere, sınıf yönetimi, öğrencilerle iletişim ve dil öğretiminde yöntem bilgisinin önde gelen özellikler olduğunu ifade etmiştir.

Sysoyev ve Evstigneev (2014) yürüttükleri araştırmada, yabancı /ikinci dil öğretimi alanında görev yapan eğiticilerin bilgi teknolojilerine hâkim olması gerektiğinin altını çizmiştir. Özellikle son y1llarda hızla artan teknolojik gelişmelerin diğer disiplinlerde olduğu gibi yabanc1/ikinci dil öğretimi alanında da önemli yenilikler getirdiğini ifade eden araştırmacılar, gelişen yeni neslin sahip olduğu teknolojik donanıma eğiticilerin de sahip olması gerektiğini belirtmiştir. Eğiticilerin bilgi teknolojileri alanında ne tür yeterliliklerinin olması gerektiğini de maddeler halinde belirten araştırmacılar, başlıca şu yeterliliklerin olması gerektiğini işaret etmiştir: akademik amaçlı kaynak arama ve bulma, internet tabanlı ödevlendirmelerde öğrencilere bilgi güvenliğini nasıl sağlayabilecekleri hakkında destek verme, internetten elde edilen bilgilerin doğruluğunu kontrol edebilme, yabancı dil öğretimi konusunda senkron-asenkron iletişim uygulamalarını kullanabilme, dil ve kültür öğretiminde Web 2.0 araçlarını kullanabilme, öğrencilerin gelişimlerini takip etmek amaciyla çevrim içi testler uygulayabilme vb.

Yabancı/ikinci dil öğretiminde görev alan eğiticilerin sahip olması gereken yeterlilikler ve özelliklerle ilgili olarak Koehler, Mishra ve Cain (2013) ise yaygın olarak kullanılan Teknoloji, Pedagoji, İçerik Bilgisi Modelinin (TPİB) önemini vurgulamışlar, günümüzde bu modele uygun eğiticilerin eğitim öğretim süreçlerini yönetmesi gerektiğini belirtmişlerdir. Söz konusu modele bakıldığında, eğiticilerin birçok özelliğinin irdelendiği görülmektedir. Hizla gelişen teknoloji çağında eğiticilerin teknoloji yeterliliğini değerlendiren, alana hâkimiyetin öneminin altını çizen ve pedagoji boyutuyla da sadece içerik bilgisini yeterli olamayacağını, eğitim öğretim sürecinin başarılı bir şekilde yürütülebilmesi için pedagoji bilgisinin de yeterli düzeyde olması gerektiği ifade edilmektedir. Dil öğretiminin yanı sıra birçok farklı alan için de uyarlaması yapılan bu model günümüzde yaygın olarak tercih edilmektedir.

Özetle; yabancılara Türkçe öğretimi süreçlerinde görev alacak eğiticilerin yeterliliklerinin münferit olarak değil devlet eliyle resmî kurumlarca doğrudan ve dolaylı paydaşların yer alacağı bir uzmanlar grubu tarafından belirlenmesi önem arz etmektedir. Türkçenin yabanci/ikinci dil olarak öğretimi, el yordamıyla, deneme yanılma yoluyla, 'ana dilim Türkçe ben de öğretebilirim' yaklaşımıyla ele alınamayacak mesleki bir disiplindir. Bu bağlamda, üniversitelerin eğitim fakültelerinde yeniden yapılandırılacak bir Türkçe Eğitimi Bölümü altında, Ana Dili Olarak Türkçe Eğitimi Anabilim Dalı, Yabancı Dil Olarak Türkçe Öğretimi Anabilim Dalı, (İkinci Dil Olarak ve) Türk Soylulara Türkçe Eğitimi Anabilim Dalı lisans programları açılmadığı sürece, Türkçenin yabancı ve ikinci dil olarak öğretiminin öğretmen yeterlilikleri ve nitelik açısından İngilizce, Almanca, Fransızca gibi dillerin aynı bağlamda öğretimi ile rekabet edebilecek düzeye yakın zamanda ulaşamayabileceği düşünülmektedir. Bu cihetle, alana özgü ögretmen yetiştirme anahtar kavram rolü üstlenmektedir. Bahsedilen süreçler, derli toplu ve devlet eliyle başlatılıncaya kadar, bir ara çözüm olarak, araştırmacılar tarafından öğretmen yeterliliklerinin dil öğretmen adaylarının görüşleri üzerinden belirlenmesine yönelik yürütülen bu araştırmanın alana sınırlı da olsa katkı sağlaması ümit edilmektedir.

\section{Araştırmanın Amacı}

Turkish Studies - Education, 15(4) 
$\mathrm{Bu}$ araştırmanın amacı, Türkçe ve İngilizce öğretmenliği lisans programlarında öğrenim gören öğretmen adaylarının yabancı dil olarak Türkçe öğretimi (YDTÖ) alanında çalışacak eğiticide bulunması gereken niteliklere, yabancı dil olarak Türkçe öğretiminde alan bilgisine, öğretim yöntemleri bilgi ve becerisi boyutlarına yönelik öz yeterlilik algılarının belirlenmesidir

\section{Alt Amaçlar}

Türkçe ve İngilizce öğretmeni adaylarının yabancılara Türkçe öğretiminde eğitici olarak öz yeterlilik algılarının belirlenmesi ve karşılaştırılmasının amaçlandığı bu araştırmada aşağıdaki sorulara cevap aranmıştır;

Yabancılara Türkçe öğretimi bağlamında; 3. ve 4. sınıf lisans programlarında öğrenim gören Türkçe ve İngilizce öğretmeni adaylarının:

1.Yabancılara Türkçe öğretimi alanında çalışan/çalışacak eğiticide bulunması gereken niteliklere yönelik görüşleri nelerdir?

2.Yabancılara Türkçe öğretimi bağlamında dil öğretim yöntemlerine yönelik bilgi ve uygulama becerisi boyutunda öz yeterlilik algıları nelerdir?

3.Yabancılara Türkçe öğretimi süreçlerinde eğitici olarak en çok zorlanacaklarını/zorlandıklarını düşündükleri öğrenme alanı ve/veya dil becerileri nedir? / nelerdir?

4.Yabancılara Türkçe öğretimi süreçlerinde (etkinlik öncesi, etkinlik sırası ve etkinlik sonrası) gerekli bilgi ve uygulama becerilerine yönelik öz yeterlilik algıları nelerdir?

\section{Araştırmanın Önemi}

İlgili literatür tarandığında, yabancı dil olarak Türkçe öğretimi (YDTÖ) alanında öğretmen yeterlilikleri üzerine yapılmış bilimsel araştırmaların sayısının sınırlı olduğu görülmektedir. Bu nitel araştırmanın, yabancı dil olarak Türkçe öğretimi bağlamında Türkçe ve İngilizce öğretmeni adaylarının öz yeterlilik algılarının belirlenmesi ve karşılaştırılması açısından alana katkı sağlayacağı düşünülmektedir.

\section{Yöntem}

\section{Araştırma Deseni}

Şekil 1. Araştırma Sürecine Yönelik Bilgiler

Desen: Nitel Araştırma Yöntemlerinden Olgubilim Deseni

Olgu: Türkçenin Yabancı Dil Olarak Öğretimi

Amaç: Türkçe ve Ingilizce öğretmenliği lisans programlarında 3. ve 4 . sınıfta öğrenim gören öğretmen adaylarının Türkçenin yabancı dil olarak öğretimi alanına yönelik öz yeterlilik algılarının belirlenmesi

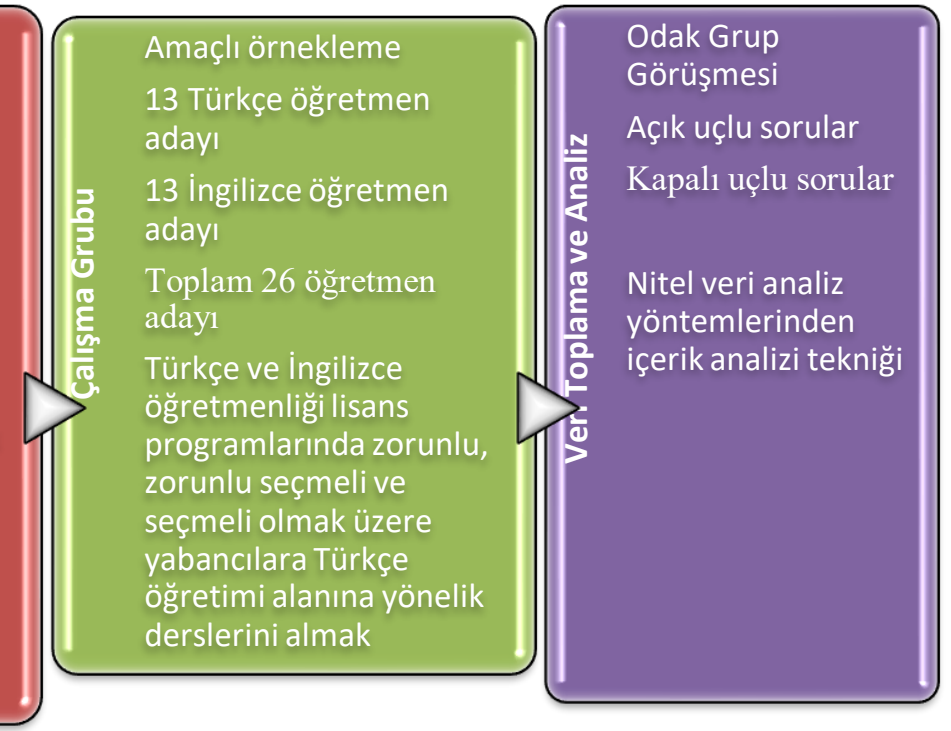


Öğretmen adaylarının yabancı dil olarak Türkçe öğretimi konusunda öz yeterlilik algıları tespit etmek amacıyla yürütülen bu araştırma, nitel araştırma desenlerinden fenomenoloji (olgubilim) desenine uygun olarak hazırlanmıştır. Olgubilim araştırmalarında genel amaç belirli bir olguyu derinlemesine anlamak, betimlemek ve katılımcıların olguyla ilgili yaşadıkları deneyimin özüne ulaşmaktır (Yıldırım ve Şimşek, 2016). Bu nedenle, bu tür araştırmalarında çalışma grubunda yer alan bireylerin olaya ilişkin tecrübeleri olması önemlidir. Bu araştırmalarda görüşme formları temel veri toplama aracı olarak kullanılmaktadır.

\section{Çalışma Grubu}

Çalışma grubu, 2018-2019 eğitim-öğretim yılı bahar döneminde bir devlet üniversitesinin Türkçe ve İngilizce Öğretmenliği Bölümlerinin 3. ve 4. sınıflarda öğrenime devam eden 26 öğretmen adayından $(13=$ Türkçe, $13=$ =̇ngiliz dili) oluşmaktadır. Katılımcılar amaçlı örnekleme yöntemlerinden kolay ulaşılabilir durum örneklemesi tekniğiyle belirlenmiştir. Katılımcıların belirlenmesinde temel ölçüt "Türkçe ve İngilizce öğretmenliği lisans programlarında zorunlu, zorunlu seçmeli ve seçmeli olmak üzere yabancılara Türkçe öğretimi alanına yönelik derslerini almak" olarak belirlenmiştir.

\section{Verilerin Toplanması ve Analizi}

Araştırma kapsamında toplanacak veriler araştırmacılar tarafından hazırlanan ve 7 yarıyapılandırılmış sorudan oluşan görüşme formu aracılığıyla toplanmıştır. Formu nihai halini alması konusunda yabancılara Türkçe öğretimi konusunda araştırmalar yapmış iki alan uzmanının görüşü alınmıştır. Uzmanlardan gelen dönütler doğrultusunda sorulardaki değişiklikler yapılarak görüşme formu hazır hale getirilmiştir.

Veriler, 2018-2019 eğitim-öğretim yılı bahar döneminde toplanmış ve işlenmiştir. Verilerin toplanma sürecinde, odak grup görüşmesi (OGG) tekniğinden yararlanılmıştır. Bu tür görüşmelerde, bireylerin sorulara verdiği cevapları grubun diğer üyelerinin de duyması, kendi fikirlerini verilen yanıtlar etrafında oluşturmasına katkı sağlamaktadır (Yıldırım ve Şimşek, 2016). Odak grup görüşmelerinde, grup dinamikleri sorulara verilen cevapların içeriğini ve derinliğini belirleyen önemli bir etken olarak öne çıkmaktadır. Gruptaki her bireyin görüşme sürecinin başında değişmez sandığ 1 görüşlerinin diğer grup üyelerinin görüşlerini dinleyince, bu bilgiler 1şığında süreç başındaki fikirlerinin kolayca değişebilmesi, yeni durumlara dönüşebilmesi OGG’nin esneklik özelliğinin kanıtıdır. Araştırma kapsamında yapılan odak grup görüşmeleri, samimi ve tehditkâr olmayan bir ortamda ve katılımcıların gönüllüğü esas alınarak yürütülmüş, katılımcıların onayları alınarak sorulara verdikleri cevaplar video kamerayla kayıt altına alınmıştır. Odak grup görüşmesi dört farklı grupla yapılmıştır (Bkz. Tablo 1). Görüşmeler tamamlandıktan sonra, ses kayıtları elektronik ortamda yazıya çevirmiş ve analiz sürecine geçilmiştir. Verilerin analizinde içerik analizi tekniğinden yararlanılmıştır. Araştırmada, katılımcıların gizliliğini sağlamak amacıyla kodlama çalışması yapılmıştır. Kodlama için iki rakam ve bir kod harfi kullanılmıştır. Kodlamada; ilk rakamlar 1'den 4'e kadar odak grup görüşmesi yapılan grupların sırasını, rakamdan sonra gelen "Ö', harfi araştırmaya katılan öğretmen adaylarını simgelemektedir. Araştırmaya katılan öğretmen adaylarını ifade eden ' $O ̈$ '” harfinden sonraki 1'den 7'ye kadar devam eden rakamlar ise görüşmedeki öğrenci sıralamasını sembolize etmektedir.

Tablo 1: Odak Grup Görüşmesine Katılan Öğretmen Adaylarıyla İlgili Bilgiler

\begin{tabular}{lccc}
\hline \multicolumn{1}{c}{ Gruplar } & Katılımcılar & Katılımcı Sayıları & OGG Süresi \\
\hline 1. Grup & Türkçe Ö. (3.sınıf) & 7 Öğretmen Adayı +1 Moderatör & 29 dakika 30 saniye \\
2. Grup & Türkçe Ö. (4.sınıf) & 6 Öğretmen Adayı +1 Moderatör & 32 dakika 35 saniye \\
3. Grup & İngilizce Ö. (3.sınıf) & 6 Öğretmen Adayı +1 Moderatör & 31 dakika 01 saniye \\
4. Grup & İngilizce Ö. (4.sınıf) & 7 Öğretmen Adayı +1 Moderatör & 34 dakika 20 saniye \\
\hline
\end{tabular}

Turkish Studies - Education, 15(4) 


\section{Bulgular}

$\mathrm{Bu}$ bölümde, araştırma kapsamında toplanan verilerin analiz edilmesi sonucu elde edilen bulgulara yer verilmiştir. İlgili bulguların sunumunda, bazı katılımcıların görüşlerine doğrudan yer verilmiştir.

\section{Birinci alt probleme ait bulgular}

Katılımcıların, birinci araştırma sorusuna "Yabancılara Türkçe öğretimi alanında çalışan/çalışacak eğiticide bulunması gereken niteliklere yönelik görüşleri nelerdir?" verdikleri cevapların analizi sonucunda elde edilen bulgular Tablo 2'de özetlenmiştir.

Tablo 2: Katılımcıların YDTÖ Sürecinde Görev Alacak/Alan Eğiticide Bulunmas1 Gereken Niteliklere Yönelik Görüşleri

\begin{tabular}{|c|c|c|c|c|c|}
\hline & Tüı & Ö. & İngi & e Ö. & \\
\hline & $\begin{array}{c}1 . \\
\text { grup }\end{array}$ & $\begin{array}{c}2 . \\
\text { grup }\end{array}$ & $\begin{array}{c}3 . \\
\text { grup }\end{array}$ & $\begin{array}{c}4 . \\
\text { grup }\end{array}$ & Toplam \\
\hline $\begin{array}{l}\text { Yabancı dil öğretimi açısından teori ve uygulama } \\
\text { bilgisine sahip olma }\end{array}$ & 1 & 7 & & 6 & 14 \\
\hline $\begin{array}{l}\text { İyi bir genel kültüre sahip olma ve hedef kitlenin } \\
\text { kültürünü bilme }\end{array}$ & & & 7 & 7 & 14 \\
\hline Yabanc1/araç dil bilme & 1 & 1 & & 7 & 9 \\
\hline Türkçe alan bilgisine hâkim olma & & 7 & & 2 & 9 \\
\hline Türk kültürüne hâkim olma & 1 & 7 & & & 8 \\
\hline $\begin{array}{l}\text { Türkçe alan bilgisine ve disiplinler arası bilgi ve } \\
\text { uygulama becerisine sahip olma }\end{array}$ & 7 & & & & 7 \\
\hline Hedef kitlenin amacinı belirleyebilme & 2 & & & & 2 \\
\hline Farklı kültürlere karşı hoşgörülü olma & 1 & & & & 1 \\
\hline Hedef kitlenin özelliklerine hâkim olma & & & & 1 & 1 \\
\hline Yurt dışı deneyimine sahip olma & 1 & & & & 1 \\
\hline Hedef kitlenin ana dil özelliklerine hâkim olma & & & & 1 & 1 \\
\hline Türkçeyi ölçünlü ve etkili kullanma & & & & 1 & 1 \\
\hline İletişimsel dil yaklaşımını kullanabilme & & & & 1 & 1 \\
\hline $\begin{array}{l}\text { Eğitim bilimleri alan bilgisi ve ölçme değerlendirme } \\
\text { bilgisine hâkim olma }\end{array}$ & & & & 1 & 1 \\
\hline $\begin{array}{l}\text { 1.grup }=\text { Türkçe Öğretmenliği 3.sınıf öğrencileri } \\
\text { 2.grup= Türkçe Öğretmenliği 4.sınıf öğrencileri }\end{array}$ & $\begin{array}{l}3 . g \\
4.9\end{array}$ & ngiliz & retm & 4.sinif & $\begin{array}{l}\text { encileri } \\
\text { encileri }\end{array}$ \\
\hline
\end{tabular}

Katılımcılara, YDTÖ eğiticisinde bulunması gereken niteliklerle ilgili görüşleri sorulduğunda elde edilen veriler aşağıdaki gibidir;

\section{Birinci gruptaki katılımcıların görüşleri aşağıdaki gibidir;}

1 ö3 kodlu 3.sınıf Türkçe öğretmeni adayı, YDTÖ eğiticisinin hedef kitlenin kültürünü bilmesi ve farklı kültürlere hoşgörülü olması gerektiğini belirtmiştir. Bir diğer katılımcı (1ö6) ise YTDÖ eğiticisinde bulunması gereken özelliklerden birinin yabanc1 dil bilmesi olduğunu vurgulamış, böylelikle özellikle temel seviyedeki (A1, A2 düzeyi) muhtemel eğitici-öğrenci iletişim sorununun ortadan kalkabileceğine vurgu yapmıştır. Katılımcı (10̈7), eğiticinin kendi kültürüne de hâkim olmasının Türk kültürünü tanıtma ve sevdirme bağlamında önemine değinmiştir. Başka bir katılımcı (1ö1), eğiticinin alan bilgisini nasıl öğreteceğini bilmesi gerektiğini, dolayısıyla yöntem ve teknik bilgisine sahip olmasının çok önemli olduğunu ifade etmiştir. Katılımcılardan bazıları (f:2), eğiticinin hedef kitlenin dil öğrenme amacını/amaçlarını belirleyerek Türkçe öğretim süreçlerini bu doğrultuda planlanması gerektiğinin altını çizmiştir. Diğer bir katılımcı (1ö5), eğiticide bulunması gereken özelliklere yurt dışı deneyimini eklemiştir. Katılımcıların tümü (f:7), eğiticinin Türkçe alan 
bilgisine hâkim olmasının yanı sıra disiplinler arası birçok alanda da bilgi sahibi olması gerektiğinin önemini vurgulamışlardır.

İkinci gruptaki katılımcıların görüşleri aşağıdaki gibidir;

$20 ̈ 3$ kodlu 4.sınıf Türkçe öğretmeni adayı, YDTÖ eğiticisinin başlangıç seviyesindeki öğretim süreçlerinde iletişim problemlerini gidermek amacıyla iyi seviyede yabancı dil bilmesi gerektiğini vurgulamıştır. Bir diğer katılımcı (20̈7), alan bilgisinin ve YTDÖ alanına yönelik yöntem bilgi ve uygulama beceresine sahip olmanın önemli olduğunu belirtmiştir. Başka bir katılımcı (2ö1) ise en önemli unsurun eğitim bilimlerine yönelik alan bilgisi ve uygulama becerisi olduğunu ve öğretmenin hedef kitleye neyi, nasıl öğreteceğini bilmesi gerektiğini belirtmiştir. Katılımc1 (2ö1): "Yabancllara Türkçe ögretecek ögretmenin öğretim yöntemlerine ve ölçme değerlendirme alanına hâkim olması gerekiyor. Çünkü bir disiplinin nasıl ögrretileceğini ve ögretim süreçlerinin nasıl değerlendirileceğini bilmek, bence yabancı dil bilmekten daha önemli ve önceliklidir." șeklinde fikir beyan etmiştir. Katılımcıların tümü (f:6), YDTÖ eğiticisinde bulunması gereken nitelikleri 'alan bilgisinde yeterlilik, dil bilgisi öğretimi ile dil becerileri alanlarının teori ve öğretim ortamlarında uygulama boyutunda yeterlilik ve hedef kitlenin kültürüyle kendi kültürüne hâkimiyet' şeklinde sıralamışlardır.

\section{Üçüncü gruptaki katılımcıların görüşleri aşağıdaki gibidir;}

3 ö4 kodlu 3.sınıf İngilizce öğretmeni adayı, YDTÖ sürecinde görev alacak eğiticinin hem ana dilinin özelliklerine hem de hedef kitlenin dilinin özelliklerine bilgi boyutunda hâkim olması gerektiğini belirtmiştir. Bir diğer katılımcı (3ö2), Türkçenin dil bilgisi yapısının eğiticiler tarafından iyi bilinmesi gerektiğini ve eğiticilerin konuşmalarında İstanbul ağzı (ölçünlü dil) kullanmasının doğru olacağını vurgulamıştır. Katılımcılar genel olarak (f:6), eğiticinin yabancı dil öğretim yöntemlerini bilmesi gerektiğini ve öğretim süreçlerinde İletişimsel Dil Öğretim Yaklaşımının kullanılması gerektiğinin altını çizmişlerdir. Katılımcıların birçoğu, (f:4) hedef kitlenin kültürünün bilinmesinin hedef dile olan merakı ve öğrenme motivasyonunu da arttırabileceği yönünde görüş belirtmiştir. Ayrıca katılımcılar (f:6), hedef kitlenin özelliklerinin bilinmesinin hedef dili öğretme sürecine katkı sağlayacağını da sözlerine eklemişlerdir.

\section{Dördüncü gruptaki katılımcıların görüşleri aşağıldaki gibidir;}

4.sınıf İngilizce öğretmeni adaylarının tamamı (f:7), YDTÖ eğiticisinin bir araç dil bilmesinin önemli olduğunu vurgulamış, özellikle başlangıç seviyesinde (A1, A2) öğretim süreçlerinde iletişim sorunlarını çözmek adına bu araç dilin kullanılabileceğini belirtmişlerdir. 4 ö3 kodlu katılımcı, "YDTÖ eğiticisinin Türkçeyi yabancı dil olarak nasıl öğreteceği konusunda bilgi ve beceri sahibi olması, aynı zamanda da Türkçe alan bilgisine hâkim olması" gerektiğini vurgulamıştır. Bir diğer katılımcı ise (4ö7), "Bunlara ek olarak, genel kültür de gereklidir. Dil ve kültür birbirinden ayrılamaz. Öğrencilere dili aktarırken sadece dil yapısını vermeyeceğim, kültürü de vermem gerekiyor ki dili canlı ve iletişimsel olarak işleyebileyim." şeklinde fikir beyan etmiştir. Katılımcıların önemli bir bölümü (f:5) bu görüşe destek vermiştir. Bir diğer katılımcı ise (4ö2) hedef kitlenin kültürünün de bilinmesi gerektiği yönünde görüş bildirmiştir. Katılımcıların tümünün (f:7), YDTÖ eğiticisinde bulunması gereken nitelikleri dil öğretim yöntemleri bilgi ve becerisi, alan bilgisi ve kültüre yönelik bilgi olarak üç ana başlık altında topladıkları görülmektedir. Katılımcılardan YDTÖ eğiticisinde bulunması gereken nitelikleri sıralaması istendiğinde, fikir birliği içinde olmadıkları ortaya çıkmıştır. Niteliklerin öncelik sırası bağlamında, 4ö2 kodlu katılımcının başlangıçta kültür ögesini ilk sırada belirttiği, diğer katılımcıları dinledikten sonra, YDTÖ eğiticisinde öncelikli olarak bulunması gereken niteliğin alan bilgisine hâkimiyet olması gerektiğini belirterek fikrini değiştirdiği görülmüştür. Sonuç olarak katılımcılardan çoğunun (f:5); alan bilgisi, yabancı dil öğretim yöntemleri bilgisi ve kültür ögesi şeklinde sıralama yaptıkları görülmektedir. 
YDTÖ sürecinde görev alacak/alan eğiticide bulunması gereken niteliklere ilişkin bulgular incelendiğinde, bu gruptaki katılımcıların tümünün Türkçe alan bilgisine sahip olma, yöntem bilgi ve uygulama becerisine sahip olma, hedef kitlenin kültürünü tanıma hususlarında hemfikir oldukları görülmektedir.

Birinci alt problem bağlamında; katılımcıların YDTÖ süreçlerinde görev alacak/alan eğiticinin mezuniyet alanın ne olması gerektiğine yönelik görüşleri, Tablo 3 ’te özetlenmiştir.

Tablo 3: Katılımcıların YDTÖ Sürecinde Görev Alacak/Alan Öğretim Elemanının Mezuniyet Alanına Yönelik Görüşler

\begin{tabular}{|c|c|c|c|c|c|}
\hline & \multicolumn{2}{|c|}{ Türkçe Ö. } & \multicolumn{2}{|c|}{ İngilizce Ö. } & \multirow[b]{2}{*}{ Toplam } \\
\hline & $\begin{array}{l}1 . \\
\text { grup }\end{array}$ & $\begin{array}{l}2 . \\
\text { grup }\end{array}$ & $\begin{array}{l}3 . \\
\text { grup }\end{array}$ & $\begin{array}{l}4 . \\
\text { grup }\end{array}$ & \\
\hline İngilizce ve Türkçe Öğretmenliği mezunları & 3 & & & 1 & 3 \\
\hline $\begin{array}{l}\text { Uygulama/staj imkânı tanınması durumunda, Türkçe } \\
\text { ögretmenliği mezunları daha başarılı olur. }\end{array}$ & 4 & & & & 4 \\
\hline Alan bilgisi yetkinliklerinden dolayı Türkçe Ö. Mezunları & 7 & 1 & & & 8 \\
\hline YDTÖ'nün kendi bölümü açılmalı ve mezunları görev almalı & 7 & 6 & 6 & 7 & 26 \\
\hline $\begin{array}{l}\text { Öğretim yöntemi yetkinliklerinden dolayı İngiliz Ö. } \\
\text { mezunları }\end{array}$ & & 3 & & & 3 \\
\hline $\begin{array}{l}\text { Türkçe Ö. bölümüne YDTÖ için uygulama/staj programı } \\
\text { eklenmeli }\end{array}$ & & 6 & & & 6 \\
\hline $\begin{array}{l}\text { Alan bilgisi yetkinliklerini tamamlamaları durumunda, } \\
\text { İngilizce Ö. mezunları }\end{array}$ & & & 5 & & 5 \\
\hline $\begin{array}{l}\text { Öğretim yöntemi konusundaki eksikliklerini tamamlamaları } \\
\text { durumunda, Türkçe Ö. mezunları }\end{array}$ & & & 5 & & 5 \\
\hline $\begin{array}{l}\text { Edebiyat kökenli bölüm mezunları yeterli yetkinliğe sahip } \\
\text { değildir. }\end{array}$ & & & & 1 & 1 \\
\hline $\begin{array}{l}\text { Diğer yabancı kültürlerle etkileşim halinde oldukları için } \\
\text { İngilizce Ö. mezunları }\end{array}$ & & & & 1 & 1 \\
\hline $\begin{array}{l}\text { 1.grup= Türkçe Öğgretmenliği 3.sınıf öğrencileri } \\
\text { 2.grup= Türkçe Öğretmenliği 4.sınıf ögrencileri }\end{array}$ & & & & & $\begin{array}{l}\text { ncileri } \\
\text { ncileri }\end{array}$ \\
\hline
\end{tabular}

Katılımcılara, YDTÖ süreçlerinde görev alacak/alan öğretim elemanlarının mezuniyet alanı ile ilgili görüşleri sorulduğunda elde edilen veriler aşağıdaki gibidir;

\section{Birinci gruptaki katılımcıların görüşleri aşağıdaki gibidir;}

3.sınıf Türkçe öğretmeni adaylarından bir kısmı (f:3), YDTÖ süreçlerinde İngilizce veya Türkçe öğretmenlerinin görev alması gerektiğini, edebiyat fakültelerinin farklı bölümlerinden (Türk dili ve edebiyatı, İngiliz dili ve edebiyatı gibi) mezun olanların, YDTÖ süreçlerini yönetmek için yeterli bilgiye ve donanıma sahip olmadığını çünkü öğretmeyi öğrenen/öğrenmiş yani formasyon bilgisine sahip kitlenin eğitim fakültesi mezunları olduğunu belirtmiştir. Diğer taraftan, katılımcılardan biri (10̈5), YDTÖ alanının başlı başına/müstakil bir bölüm açılarak taçlandırılması gerektiğini, İngilizce öğretmenliği ve Türkçe öğretmenliği mezunlarının YDTÖ süreçlerini yönetmek için tam anlamıyla yetkin olmadığını vurgulamıştır. Bu gruptaki Türkçe öğretmeni adaylarının tümü (f:7), katılımcının (1ö5) bu görüşüne iştirak etmişlerdir. Diğer bir katılımcı ise (10̈2) YDTÖ bağlamında sertifika programlarının yetersizliğini gündeme getirmiş, bu tür sertifika programlarının uygulama boyutundaki eksikliklerden dolayı öğretmen yetiştirmede yetersiz kaldığını sözlerine eklemiştir. Bu gruptaki katılımcıların birçoğu (f:4), Türkçe öğretmenliği lisans programlarında YDTÖ’ye yönelik derslerin uygulamaya dönük olması koşuluyla, yabancılara Türkçe öğretimi süreçlerinde Türkçe öğretmenlerinin daha başarılı olacağının altını çizmiştir. Katılımcı (10̈2), yabancı dil bilmeleri nedeniyle İngilizce öğretmenlerinin YDTÖ süreçlerinde daha başarılı olacağını ifade etmiştir. Bir diğer katılımcı (1ö7), bu görüşe katılmayarak başlangıç 
seviyesindeki öğrenciler için eğiticinin yabancı bir araç dili bilmesinin bir avantaj olabileceğini ancak ilerleyen seviyelerde etkili bir yabancı dil öğretim süreci yürütülebilmesi için eğiticinin Türkçeye alan bilgisi bağlamında tam anlamıyla hâkim olmasının yabancı dil bilgisinden daha önemli olduğunu sözlerine eklemiştir. Sonuç olarak, 3. sınıf Türkçe öğretmeni adaylarının birçoğu (f:6); Türkçenin yabancı dil olarak öğretimi süreçlerinde, Türkçe öğretmenlerinin Türkçe alan bilgisi, İngilizce öğretmenlerinin ise yabancı dil öğretimine yönelik yöntem bilgi ve uygulama becerisi bağlamında daha yetkin olduğunu düşünmektedir.

\section{İkinci gruptaki katılımcıların görüşleri aşağıdaki gibidir;}

2 ö6 kodlu 4.sınıf Türkçe öğretmeni adayı, Türkçe alan bilgisi yetkinliğinden dolayı YDTÖ süreçlerinin en etkili şekilde Türkçe öğretmenliği mezunları tarafından yürütülebileceğini belirtmiştir. Buna karşın, katılımcıların bir kısmı (f:3), yabancı dil öğretim yöntemleri bilgi ve uygulama becerisi bağlamında yabancı dil mezunlarının daha donanımlı olduklarını düşündükleri için yabancı diller eğitimi bölümlerinden mezun olanların YDTÖ süreçlerinde daha başarılı olacağını savunmuşlardır. Katılımcılardan biri (2ö1), farklı bölümlerden mezun olanların YDTÖ süreçlerinde yetersiz ve etkisiz kalacağını, yabancılara Türkçe öğretimi lisans programının müstakil olarak açılması gerektiği fikrini ortaya atmıştır. Diğer katılımcılar ise (f:5) bu görüşe katıldıklarını ancak YDTÖ lisans programlarının açılıp açılmayacağının hala belli olmadığını, yakın gelecekte ilgili kurum ve kuruluşlarca açılması kararının alınması durumunda dahi bu sürecin uzun zaman alabileceğini ifade etmiştir. $\mathrm{Bu}$ bağlamda katılımcılar (f:5), Türkçe öğretmenliği lisans programlarında, YDTÖ alanına yönelik derslerin sayı ve çeşitlilik bağlamında arttırılması, içerik bağlamında zenginleştirilmesi ve öğretmen adaylarına staj imkânı sağlanması fikrini çözüm önerisi olarak dile getirmiştir. Ayrıca, 4. sınıf Türkçe öğretmeni adaylarının tümünün (f:6), Türkçe öğretmenliği lisans programına yabanc1lara Türkçe öğretimine yönelik en az 14 haftalık bir staj uygulamasının dâhil edilmesi konusunda fikir birliği içinde oldukları görülmektedir.

\section{Üçüncü gruptaki katılımcıların görüşleri aşağıdaki gibidir;}

3.sınıf İngilizce öğretmeni adayları genel olarak (f:5), YDTÖ süreçlerinde görev alacak/alan eğiticilerin, alan bilgisi ve yabancı dil öğretim yöntemleri konusundaki eksiklikleri tamamlamak şartıyla, İngilizce ve Türkçe öğretmenliği lisans programları mezunlarından olması gerektiğini belirtmişlerdir. Alandaki liyakat karmaşası ve çekişmesinin ise aday YDTÖ eğiticisine uygulanacak mülakat/sözlü sınavla çözülebileceğini, böylelikle YDTÖ bağlamında kimin daha yetkin olduğunun belirlenebileceğini sözlerine eklemiştir. İngilizce öğretmeni adaylarından bir kısmı (f:3), alanda açılmış çok sayıdaki sertifika programının kalitesizliğine değinmiş; kısa süreli bu tür sertifika programlarının YDTÖ ortamlarına nitelikli öğretmen yetiştirmek gerçeğinden uzak olduğunu vurgulamıştır. 3.sınıf İngilizce öğretmeni adaylarının tümü (f:6), YDTÖ’nün başlı başına ayrı/müstakil bir disiplin olduğunu belirtmiştir. Ayrıca, bu gruptaki katılımcıların tümünün, eğitim fakülteleri bünyesinde Türkçe ve İngiliz dili eğitimi anabilim dallarından bağımsız, müstakil bir lisans programı açılmasının YDTÖ süreçlerinde karşılaşılan sorunlara uzun vadeli ve kesin çözüm olabileceği konusunda fikir birliği içinde oldukları görülmektedir.

Dördüncü gruptaki katılımcıların görüşleri aşă̆ıdaki gibidir;

4 ö5 kodlu 4.sınıf İngilizce öğretmen adayı, öğretim formasyonuna yönelik dersleri almış olmanın öneminin altını çizerek edebiyat fakültesindeki öğrencilerin daha çok teori boyutunda eğitim aldıklarını, eğitim fakültelerinde ise uygulamaya yeteri kadar yer verildiğini belirtmiştir. Aynı katılımc1, bu nedenle eğitim fakültesi öğrencilerinin YDTÖ süreçlerinde daha başarılı olacağını sözlerine eklemiştir. Bir diğer katılımcı (4ö3), YDTÖ süreçlerinde Türkçe öğretmenlerinin yabancı dil öğretim yöntemlerine yönelik bilgi ve uygulama becerisi, İngilizce öğretmenlerinin ise Türkçe alan bilgisi bağlamında yetersiz kalacağını ifade etmiştir. Bu nedenle, 'YDTÖ alanına yönelik müstakil bir anabilim dalı kurulmalı' önerisinde bulunmuştur. Katılımcıların tümü (f:7), bu görüşü öne süren katılımcıyı (4ö3) destekler yönde fikir beyan etmiştir. Başka bir katılımcı (4ö1), Türkçe 
öğretmenlerine yabancı dil öğretim yöntemlerine, İngilizce öğretmenlerine ise Türkçe alan bilgisine yönelik dersler verilerek eksikliklerin bir nebze de olsa giderilebileceği fikrini geçici/kısa vadeli bir çözüm önerisi olarak ortaya atmıştır. Son olarak bir katılımcı (4ö4), İngilizce öğretmenlerinin diğer kültürlerle daha çok etkileşim içinde olması nedeniyle YDTÖ süreçlerinde Türkçe öğretmenlerine göre daha başarılı olacağını ifade etmiştir.

YDTÖ süreçlerinde görev alacak/alan öğretim elemanlarının mezuniyet alanı söz konusu olduğunda, Türkçe ve İngilizce öğretmenliği lisans programı mezunlarının diğer alanlardan/bölümlerden/programlardan mezun olanlara oranla daha başarılı olacağı konusunda katılımcıların fikir birliği içinde olduğu görülmektedir. Bununla beraber, YDTÖ lisans programının müstakil bir program olarak bir an önce açılması ve söz konusu alan mezunlarının YDTÖ süreçlerinde görev almaya başlaması gerektiğini ortak görüş olarak belirtmişlerdir.

Birinci alt problem bağlamında; katılımcılar tarafından YDTÖ alanında görev alacak/alan öğretim elemanlarının yabancı bir dil bilmesinin dil öğretimine etkisiyle ilgili soruya verilen cevaplar Tablo 4'te özetlenmiştir.

Tablo 4: YDTÖ Eğiticisinin Yabancı Bir Dil Bilmesinin Dil Öğretimine Etkisiyle İlgili Katılımcı Görüşleri

\begin{tabular}{|c|c|c|c|}
\hline \multirow{9}{*}{ 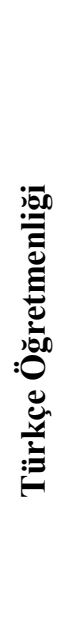 } & Gruplar & Görüşler & $f$ \\
\hline & \multirow{4}{*}{ (1.grup) } & Yabanc1/araç dilin Temel Seviye'de (A1, A2) kullanılması yararlıdır. & 1 \\
\hline & & $\begin{array}{l}\text { Yabancı/araç bir dil bilmek yurt dışında görev yapan YDTÖ eğiticisine } \\
\text { kolaylık sağlar. }\end{array}$ & 7 \\
\hline & & & 2 \\
\hline & & Hedef kitlenin dilinin bilinmesi karşılaştırmalı öğretim imkânı sağlar. & 1 \\
\hline & \multirow{5}{*}{ (2.grup) } & $\begin{array}{l}\text { YDTÖ süreçleri yurt dışında yürütülüyorsa yabancı/araç bir dil } \\
\text { bilinmelidir. }\end{array}$ & 6 \\
\hline & & $\begin{array}{l}\text { YDTÖ alanına yönelik yabancı dilde yazılmış bilimsel kaynaklardan } \\
\text { yararlanmak için yabancı dil bilmek gerekir. }\end{array}$ & 1 \\
\hline & & $\begin{array}{l}\text { Hedef kitlenin dili bilinirse öğrenciler arasındaki etkileşimden de } \\
\text { haberdar olunabilir. }\end{array}$ & 1 \\
\hline & & $\begin{array}{l}\text { Ders içinde kesinlikle Türkçe dışında yabancı bir dil } \\
\text { kullanılmamalıdır. }\end{array}$ & 6 \\
\hline \multirow{8}{*}{ 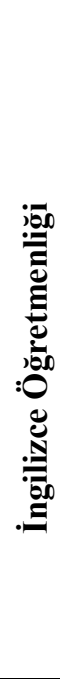 } & & Hedef kitlenin dilinin bilinmesi karşılaştırmalı öğretim imkânı sağlar. & 1 \\
\hline & \multirow{4}{*}{ (3.grup) } & $\begin{array}{l}\text { Yabancı dil bilmek, eğiticinin kendi öğrenim süreciyle } \\
\text { (deneyimleriyle) empati kurmasını sağlar. }\end{array}$ & 1 \\
\hline & & $\begin{array}{l}\text { Hedef kitlenin dilinin ve kültürünün bilinmesi eğiticiye ve öğretilen } \\
\text { dile karşı öğrenciler tarafindan olumlu tutum geliştirilmesini sağlar. }\end{array}$ & 3 \\
\hline & & $\begin{array}{l}\text { Yabancı bir dilin ders içinde A1 seviyesinde kullanımı öğrenci } \\
\text { motivasyonunu arttırır. }\end{array}$ & 5 \\
\hline & & $\begin{array}{l}\text { Yabancı dil bilmek, yurt dışında görev yapacak/yapan YDTÖ } \\
\text { eğiticisinin hayatını kolaylaştırır. }\end{array}$ & 5 \\
\hline & \multirow{3}{*}{ (4.grup) } & $\begin{array}{l}\text { Temel Seviye'de (A1, A2) anlaşılmayan noktaları açıklamak için } \\
\text { yabancı bir dili araç dil olarak bilmek ve kullanmak gereklidir. }\end{array}$ & 7 \\
\hline & & $\begin{array}{l}\text { Yabancı bir dili araç dil olarak bilmek ve kullanmak ders içi ve ders } \\
\text { dışı iletişim problemlerini çözmeyi sağlar. }\end{array}$ & 1 \\
\hline & & $\begin{array}{l}\text { YDTÖ süreçlerinin yürütüldüğü ortamda, sosyal çevreyle etkileşim } \\
\text { için yabancı bir dil bilmek gereklidir. }\end{array}$ & 7 \\
\hline & & 3.grup= İngilizce Öğretmenliği $3 . \mathrm{s}$ & \\
\hline & Türkçe Ċ & 4.grup= İngilizce Öğretmenliği 4.sını & iler \\
\hline
\end{tabular}


Katılımcılara, YDTÖ süreçlerinde görev alacak eğiticilerin yabancı bir dil bilmesinin dil öğretim süreçlerine etkisiyle ilgili görüşleri sorulduğunda elde edilen veriler aşağıdaki gibidir;

Birinci gruptaki katılımcılardan elde edilen veriler aşağıdaki gibidir;

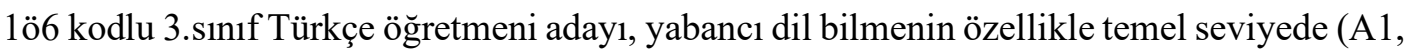
A2) öğrencilerle anlaşabilmek için iletişim dili olması bakımından gerekli olduğunu savunmuştur. Öğretmen adaylarından bir kısmı (f:2), yabancı dil bilmenin yurt dışındaki YDTÖ süreçlerinde görev alacak/alan eğiticiye sosyal/günlük hayatı kolaylaştırması açısından katkısı olduğunu ancak Türkçe derslerinde yabanc1/araç bir dil kullanılmaması gerektiğini belirtmiştir. Aynı zamanda, yalnızca temel seviyede (A1, A2) yabanc1/araç bir dil kullanılmasının ve sonraki aşamalarda bu stratejinin terk edilmesinin, hedef dilin/Türkçenin öğrenilme ve öğretilme süreçlerine olumsuz etkileri olabileceğini sözlerine eklemiştir. Diğer taraftan, bir diğer katılımcı (1ö3) ise hedef kitlenin dilini bilmenin karşılaştırmalı yabancı dil öğretimi ortamlarına firsat sağlayacağını ve Türkçenin yabancı dil olarak öğretimi süreçlerine olumlu katkı sağlayacağını belirtmiştir. Katılımcıların tümü (f:7), "YDTÖ eğiticisi yurt dışına gidip orada Türkçe öğretecekse kesinlikle yabancı dil bilmelidir" görüşünü savunmuş̧tur.

\section{İkinci gruptaki katılımcılardan elde edilen veriler aşă̆ğdaki gibidir;}

4.sınıf Türkçe öğretmeni adaylarının tümü (f:6), Türkçenin yabancı dil olarak yurtdışında öğretildiği durumlarda öğretim elemanın yabancı bir dil bilmesinin gerekli olduğunu belirtmiştir. 2ö1 kodlu Türkçe öğretmeni adayı, yurt dışında ders dışı etkinliklerde, çevreyle, öğrencilerle, çalıştığ 1 kurumla iletişim kurabilmek için eğiticinin yabancı bir dil bilmesinin şart olduğunu vurgulamıştır. Bir diğer katılımcı (2ö3), yabancı dil alanına yönelik yayımlanan, özellikle İngilizce ağırlıklı, bilimsel başvuru kaynaklarının çok olduğunu, yabancı dil bilgisi sayesinde birincil kaynaktan bilgi edinilebileceğini ve bunun eğitici için önemli bir avantaj olduğunu ifade etmiştir. Başka bir katılımcı (2ö6), hedef kitlenin dilini bilmenin o ülkenin kültürüne de aşina olmak anlamına geldiğini ve bu sayede öğrencilerle daha etkili bir iletişim kurulabileceğini sözlerine eklemiştir. Bir diğer katılımc1 (20̈4), yabancı bir dil bilmenin araç dil ve hedef dile ait kuralları karşılaştırmak ve örneklerle öğrencilere karşılaştırmalı olarak açıklamak bağlamında eğitici, öğrenci, öğrenim ve öğretim ortamları lehine avantaj sağlayacağını belirtmiştir. 4.sınıf Türkçe öğretmeni adaylarının tümü (f:6), Türkçenin yurtdışında öğretildiği YDTÖ süreçlerinde görev alacak/alan eğiticinin, yabancı bir dil bilmesinin önemli bir avantaj olduğunu ancak eğiticinin ders içinde kesinlikle hedef dili/Türkçeyi kullanması gerektiğini vurgulamıştır.

\section{Üçüncü gruptaki katılımcılardan elde edilen veriler aşağıdaki gibidir;}

3 ö5 kodlu İngilizce öğretmeni adayı, yabancı dil bilen eğiticinin kendi dil öğrenimi deneyimleriyle görev yapacağı/yaptığı yeni dil öğretimi ortamları arasında karşılaştırma yapabileceğini, empati yoluyla kendi yabancı dil öğrenimi deneyimlerini görev alacağı/aldığ 1 YDTÖ süreçlerine uyarlayabileceğini ifade etmiştir. Katılımcılardan bir kısmı (f:3), hedef kitlenin dilinin ve kültürünün Türkçe eğiticisi tarafindan bilinmesinin, öğrenciler tarafindan eğiticiye karşı olumlu tutum geliştirilmesine katkı sağlayacağını belirtmiştir. Bazı katılımcılar (f:2), ders içinde sadece A1 düzeyinde yabancı bir dilin kullanılması gerektiğini, böylelikle öğrencilerin Türkçe öğrenme motivasyonun da arttırılabileceğini ifade etmiştir. Katılımcılar genel olarak (f:5), yabancı/araç dilin ders içinde temel seviyede (A1, A2) kullanılabileceğini ve sosyal çevreyle etkileşim kurmak için eğiticinin yabanc1 dil bilmesinin gerekli olduğunu vurgulamıştır.

\section{Dördüncü gruptaki katılımcılardan elde edilen veriler aşă̆ıdaki gibidir;}

4 ö4 kodlu 4.sınıf İngilizce öğretmeni adayı, Türkçe öğretim süreçlerinde anlaşılmayan, açıklanması zor noktaların hedef kitlenin diliyle veya ortak bir yabancı/araç dille açıklanabileceğini, dolayısıyla dil bilmenin bu anlamda avantaj sağlayacağını ifade etmiştir. Bir diğer İngilizce öğretmeni adayı (4ö7), ders içi ve ders dışı iletişim problemlerini çözebilmek için yabancı/araç bir 
dilin mutlaka bilinmesi gerektiğini ifade etmiştir. Katılımcıların tümünün (f:7), yabancı/araç bir dil bilmenin gerekli olduğu ve ders içinde A1 seviyesinde kullanılabileceği konusunda fikir birliği içinde oldukları görülmüştür. Aynı zamanda tüm katılımcıların, sosyal çevreyle iletişim kurmada da yabancı bir dilin gerekli olduğu konusunda hemfikir oldukları görülmüştür.

YDTÖ eğiticisinin yabancı bir dil bilmesinin dil öğretimine etkisiyle ilgili katılımcı görüşleri incelendiğinde; 4.sınıf İngilizce öğretmeni adaylarının, Türkçenin yurtdışında öğretildiği durumlarda, eğiticinin yabanc1/araç bir dil bilmesi gerektiği konusunda hemfikir olduğu görülmektedir. Ayrıca katılımcılar, YDTÖ süreçlerinde özellikle temel seviyede (A1, A2) sınırlı düzeyde yabancı/araç dil kullanımının Türkçe öğretim ortamlarına olumlu katkı sağlayacağı noktasında görüş birliği içindedir.

\section{İkinci alt probleme ait bulgular}

Yabancılara Türkçe öğretimi bağlamında; dil öğretim yöntemlerine yönelik bilgi ve uygulama boyutunda katılımcıların öz yeterlilik algılarına ilişkin görüşleri Tablo 5 'te özetlenmiştir.

Tablo 5: Katılımcıların Yabancılara Türkçe Öğretimi Bağlamında Dil Öğretimi Yöntemlerine Yönelik Bilgi ve Beceri Boyutlarında Öz Yeterlilik Algıları

\begin{tabular}{|c|c|c|c|c|c|}
\hline & \multicolumn{2}{|c|}{$\begin{array}{c}\text { Türkçe } \\
\text { Öğretmenliği }\end{array}$} & \multicolumn{2}{|c|}{$\begin{array}{c}\text { İngilizce } \\
\text { Öğretmenliği } \\
\end{array}$} & \multirow{2}{*}{ Toplam } \\
\hline & $\begin{array}{l}\text { grup } \\
\text { grus }\end{array}$ & $\begin{array}{l}2 . \\
\text { grup }\end{array}$ & $\begin{array}{l}3 . \\
\text { grup }\end{array}$ & $\begin{array}{ll}. \\
\text { grup }\end{array}$ & \\
\hline Hem teori ve uygulamada yeterli görme & & & 2 & 5 & 7 \\
\hline Teoride yeterli, uygulamada yetersiz görme & 1 & & & 1 & 2 \\
\hline Yetersiz görme & 4 & & 2 & & 6 \\
\hline $\begin{array}{l}\text { Mevcut alanında verilen eğitimin YDTÖ için yetersiz } \\
\text { olduğunu düşünme }\end{array}$ & 4 & & & & 4 \\
\hline $\begin{array}{l}\text { Mevcut alanında YDTÖ’ye eğitimin verilmesi } \\
\text { gerektiğini düşünme }\end{array}$ & & & 1 & & 1 \\
\hline $\begin{array}{l}\text { Başlangıç seviyesi (A1) için yeterli hissetme, ileriki } \\
\text { seviyeler için zorlanabileceğini düşünme }\end{array}$ & 1 & & & & 1 \\
\hline $\begin{array}{l}\text { YDTÖ için özel bir alan eğitiminin olması } \\
\text { gerektiğini düşünme }\end{array}$ & & & & 1 & 1 \\
\hline $\begin{array}{l}\text { Eksikliklerini tamamlaması durumunda yeterli } \\
\text { olacağını düşünme }\end{array}$ & 1 & & & & 1 \\
\hline $\begin{array}{l}\text { 1.grup= Türkçe Öğretmenliği 3.sınıf öğrencileri } \\
\text { 2.grup= Türkçe Ögretmenliği 4.sınıf ögrencileri }\end{array}$ & $\begin{array}{l}3.9 \\
4.9\end{array}$ & S1l1: & . & $\begin{array}{l}. s i n i f \\
. \sin 1 f\end{array}$ & $\begin{array}{l}\text { ncileri } \\
\text { ncileri }\end{array}$ \\
\hline
\end{tabular}

Birinci gruptaki katılımcılardan ikinci alt probleme ait elde edilen veriler aşağıdaki gibidir;

3.sınıf Türkçe öğretmeni adaylarından birçoğu (f:4), yabancılara Türkçe öğretimi bağlamında yabancı dil öğretim yöntemleri, teknikleri ve materyal kullanımıyla ilgili bilgi/teori ve beceri/uygulama boyutunda yetkin olmadıklarını belirtmiştir.

Sadece bir katılımcı (1ö6), yabancılara Türkçe öğretimi bağlamında yabancı dil öğretim yöntemleri ve materyal kullanımına yönelik bilgi ve beceri/uygulama donanımının A1 düzeyinde yeterli olabileceğini ifade ederken, daha üst dil düzeyleri için yeterli bilgi ve beceriye sahip olmadığını belirtmiştir. Başlangıç düzeyinde (A1), uygun materyal tasarlayabileceğini, iletişimi sağlayacak düzeyde İngilizce bilgisine sahip olmasının öğretim süreçlerinde işini kolaylaştıracağını ifade etmiştir. Bu görüşe katılımcılardan bazıları (f:2) iştirak etmeyerek Türkçe öğretmenliği lisans programında yabancı dil öğretim yöntemleri bilgi ve uygulama becerisine yönelik aldıkları eğitimin, YDTÖ süreçlerinde eğitici olarak başarılı olmak için yetersiz olduğunu dile getirmiştir. Özellikle, A1 düzeyinde yabancılara Türkçe öğretmenin kolay olmadığını, eğitici açısından en zor düzeyin A1 olduğunu ifade etmişlerdir. 
Diğer bir katılımcı ise (10̈3), konuya farklı bir açıdan bakılması gerektiğini vurgulayarak Türkçe öğretmeni olarak ana dili Türkçe olan öğrencilere Türkçe öğretmek amacıyla eğitim aldıkları için, bir yabancıya Türkçe öğretmenin çok daha farklı bilgi ve beceri gerektirdiğini belirtmiştir. Bu

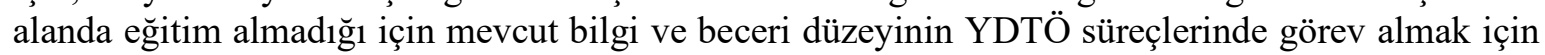
yeterli olmadığını sözlerine eklemiştir. Bu konuda, aynı fikirde olan bir diğer katılımcı (10̈4), yabancılara Türkçe öğretimine yönelik eğitim almadıklarını yineleyerek yabancı dil öğretim yöntemleri bilgi, uygulama becerisi ve materyal tasarımı, kullanımı konusunda yeterli mesleki donanıma sahip olmadığını belirtmiştir. Diğer bir katılımcı (10̈7), konuya yeni bir boyut ekleyerek yabancılara Türkçe öğretimi konusunda eğiticinin öz güven sahibi olmasının da önemli olduğunu vurgulamıştır. Ayrıca, YDTÖ’ye yönelik mesleki bilgi ve beceri açısından eksikleri olmakla birlikte, kendini geliştirebileceğini düşündüğünü sözlerine eklemiştir.

\section{Ikinci gruptaki katılımcılardan ikinci alt probleme ait elde edilen veriler aşağıdaki gibidir;}

4.sınıf Türkçe öğretmeni adaylarının birçoğu (f:4), yabancılara Türkçe öğretimi bağlamında yabanc1 dil öğretim yöntemlerine ve materyal kullanımına yönelik bilgi ve beceri boyutunda kendilerini yetersiz hissettiklerini ifade etmektedir. Ana dili Türkçe olanlara Türkçe öğretme konusunda kendilerini daha yetkin hissettiklerini çünkü bu alanda staj/uygulama firsatı/deneyimi bulduklarını ifade etmişlerdir. Yabancılara Türkçe öğretiminin ise farklı bir alan/disiplin olduğunu ve bu alana yönelik yeterli eğitimi alamadıkları için kendilerini yetersiz hissettiklerini belirtmişlerdir. Bir katılımcı (2ö6), yabancılara Türkçe öğretiminde Türkçe alan bilgisi boyutunda kendini yeterli, yabancı dil öğretim yöntemleri ve materyal kullanımı/tasarımı boyutunda bilgi ve uygulama düzeyinde ise donanımsız hissettiğini vurgulamıştır. Bu duruma, uygulama dersleri ve staj uygulaması eksikliğinin neden olduğunu ifade etmiştir. Ayrıca katılımcı (2ö4), YDTÖ alanında uygulama/staj eksikliğinin büyük bir sorun olduğunu vurgulamış, yabancı dil öğretim yöntemleri bilgi ve uygulama becerisi boyutundaki sorunların ise araştırma yaparak kişisel çabalarla giderilebileceğini belirtmiştir.

\section{gibidir;}

Üçüncü gruptaki katılımcılardan ikinci alt probleme yönelik elde edilen veriler aşağılaki

3.sınıf İngilizce öğretmeni adaylarından bazıları (f:2), Türkçe alan bilgisi boyutunda kendilerini yeterli görmemelerine karşın, yabancı dil öğretim yöntemleri bağlamında bilgi ve uygulama düzeyinde donanımlı olduklarını ifade etmiştir. Katılımcılardan bazıları (f:2) ise yabancı dil öğretim yöntemleri bağlamında bilgi ve uygulama düzeyinde yetkin olmanın, yabancılara Türkçe öğretmek için yeterli nitelikler olmadığını belirterek bir önceki görüşe katılmadıklarını ifade etmişlerdir. Diğer bir katılımcı ise (3ö5) yabanc1 dil öğretim yöntemleri bilgi, uygulama becerisi ve Türkçe alan bilgisi bağlamında yetkin olduğunu, bireysel olarak bir yabanciya Türkçe öğretebileceğini belirtmiş̧tir. Diğer taraftan, kendisine müstakil bir sınıf/grup verilmesi durumunda öğretim süreçlerini yönetemeyeceğini ifade etmiştir. Bir katılımcı (3ö2), YDTÖ’ nün özel bir alan olduğunu belirterek Türkçe öğretim süreçlerinde, bu alana yönelik özel eğitim alanların görev alması gerektiğini ifade etmiştir.

\section{Dördüncü gruptaki katılımcılardan ikinci alt probleme yönelik elde edilen veriler aşağıdaki} gibidir;

4.sınıf İngilizce öğretmeni adaylarından birçoğu (f:5), yabancılara Türkçe öğretimi bağlamında yabancı dil öğretim yöntemleri bilgi ve uygulama becerisi boyutunda kendilerini yetkin hissettiklerini ifade etmiştir. Grup üyelerinin çoğu (f:5), İngilizce öğretmenliği lisans programında almış oldukları eğitim sayesinde, yabancı dil öğretim yöntemleri bilgi ve uygulama boyutunda yetkin olduklarını ve YDTÖ süreçlerini yönetebileceklerini, amaca uygun materyal tasarlayabileceklerini ifade etmişlerdir. Diğer taraftan, kendilerini Türkçe alan bilgisi konusunda yetkin hissetmediklerini de sözlerine eklemişlerdir. Bir diğer katılımcı (4ö5), yabancılara Türkçe öğretiminin özel bir alan olduğunu belirterek sadece bu amaca yönelik bir lisans programının açılması gerekliliği üzerinde 
durmuştur. Diğer bir katılımcı (4ö4) ise yabancı dil öğretim yöntemleri bilgi, uygulama becerisi ile materyal tasarlama ve uygulama boyutunda kendini yetkin hissetmediğini, Türkçe alan bilgisi ve kültür boyutlarında ise yeterli donanıma sahip olduğunu belirtmiştir.

Yabancılara Türkçe öğretimi bağlamında yabancı dil öğretim yöntemlerine ve materyal kullanımına/tasarımına yönelik bilgi ve beceri boyutunda öz yeterlilik algılarıyla ilgili katılımcılardan elde edilen bulgular incelendiğinde, Türkçe öğretmeni adaylarının kendilerini yetkin hissetmedikleri görülmektedir. Diğer taraftan, İngilizce öğretmeni adayları ise genel olarak, YDTÖ süreçlerinde yabancı dil öğretim yöntemleri, bilgi ve uygulama becerisi ile materyal kullanımı/tasarımı bağlamında kendilerini yeterli hissettiklerini ifade etmişlerdir.

\section{Üçüncü alt probleme ait bulgular}

Katılımcıların, yabancılara Türkçe öğretimi süreçlerinde eğitici olarak en çok zorlanacaklarını düşündükleri dil becerilerine ve öğrenme alanına yönelik görüşleri Tablo 6'da özetlenmiştir.

Tablo 6: Katılımcıların YDTÖ Süreçlerinde Eğitici Olarak En Çok Zorlanacaklarını Düşündükleri Dil Becerileri ve Öğrenme Alanına Yönelik Görüşleri

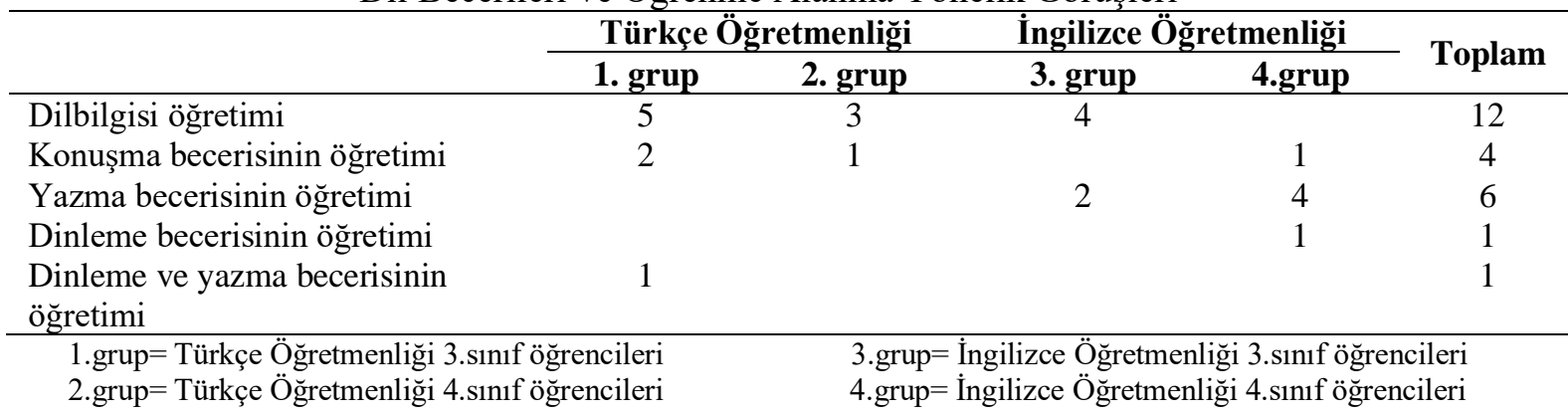
gibidir:

Birinci gruptaki katılımcılardan üçüncü alt probleme yönelik elde edilen veriler aşağıdaki

3.sınıf Türkçe öğretmeni adaylarından bazıları (f:2), YDTÖ süreçlerinde en çok zorlanacakları alanın dil bilgisi öğretimi olabileceğini belirtmiștir. Bunun nedenini ise kendilerini bu konuda donanımlı ve yetkin hissetmemelerine bağlamışlardır. Katılımcıların bir kısmı (f:2), en çok Türkçe konuşma becerisi ve sesletim öğretimi süreçlerinde zorlanabileceklerini belirtmişlerdir. Katılımcılardan bazıları (f:3), hedef kitlenin diliyle Türkçe arasındaki dil bilgisel farklılıklardan dolayı, dil bilgisi öğretiminde zorlanabileceklerini ifade etmişlerdir. Katılımcılardan biri (1ö6), dil becerisi bağlamında telaffuz ve yazı dili arasındaki farklardan dolayı, dinleme ve yazma becerilerinin öğretiminde zorlanacağını vurgulamıştır. gibidir:

İkinci gruptaki katılımcılardan üçüncü alt probleme yönelik elde edilen veriler aşağıdaki

4.sınıf Türkçe öğretmeni adaylarından bazıları (f:2), YDTÖ alanında yeterli bir eğitim almamalarını ve öğrencileri nasıl güdüleyeceklerini bilmemelerini gerekçe göstererek daha çok Türkçe konuşma becerisinin öğretiminde zorlanabileceklerini ifade etmiştir. Katılımcılardan biri (20̈4), dil bilgisi öğretiminin sezdirerek yapılması gerektiğini belirtmiş ve temel seviyede dil bilgisi öğretimine daha fazla zaman ayrılacağını ifade ederek dil bilgisinin öğretiminde kendini yetkin hissettiğini sözlerine eklemiştir. Diğer bir katılımcı (2ö6), konuşma becerisi öğretiminde daha çok zorlanabileceğini belirtmiștir. Bununla beraber, dinleme ve yazma becerilerinin öğretimi süreçlerinde kendine güvendiğini de sözlerine eklemiştir. Katılımcıların tümü (f:6), konuşma ve yazma becerilerinde, bir başka deyişle, anlatma becerilerinin öğretiminde zorlanabileceklerini ortak görüş olarak dile getirmişlerdir. 

gibidir:

Üçüncü gruptaki katılımcılardan üçüncü alt probleme yönelik elde edilen veriler aşağıdaki

3.sınıf İngilizce öğretmeni adaylarının birçoğu (f:4), Türkçe dil bilgisi alanında yeterli bilgiye sahip olmadıklarını düşündükleri için en çok bu öğrenme alanının öğretiminde zorlanacaklarını ifade etmişlerdir. Katılımcılardan bazıları (f:2), çok sık kullanılan bir beceri olmadığı için ve günlük hayatta pratik yapma şansı da olamayacağı için en çok Türkçe yazma becerisinin öğretiminde zorlanabileceklerini belirtmişlerdir.

Dördüncü gruptaki katıllmcllardan üçüncü alt probleme yönelik elde edilen veriler aşă̆ıldaki gibidir:

4.sınıf İngilizce öğretmeni adaylarının çoğu (f:4), kendilerini Türkçe yazma becerisinin öğretiminde yetkin görmedikleri için özellikle ilerleyen seviyelerde en çok bu becerinin öğretiminde zorlanabileceklerini belirtmişlerdir. Aynı zamanda, yazma becerisinin gelişiminde, öğrencilerin ilerleme kaydetmesini sağlamanın zor olabileceğini sözlerine eklemişlerdir. Katılımcılardan biri (4ö4), Türkçe konuşma becerisinin diğer dil becerilerine göre daha geç geliştiğini düşündüğü için öğretim süreçlerinde en çok zorlanacağı alanın konuşma becerisi öğretimi olabileceğini vurgulamıştır. Başka bir katılımcı (4ö2), Türkçe dinleme becerisinin öğretiminde zorlanabileceğini ifade etmiştir. Bunun nedenini, dinleme süreçlerinde materyal kullanımına ve yabancı dil öğretim yöntemlerine yönelik bilgi ve uygulama boyutundaki donanım eksikliğine bağlamıştır.

Katılımcıların, yabancılara Türkçe öğretimi süreçlerinde eğitici olarak en çok zorlanacaklarını düşündükleri dil becerilerine yönelik görüşlerine ait bulgular incelendiğinde, tümünün yazma becerisinin öğretimi süreçlerinde zorlanabilecekleri konusunda hemfikir oldukları görülmektedir. Aynı zamanda, Türkçe ve İngilizce öğretmenliği lisans programlarında 3.sınıfta öğrenim gören katılımcılar, dil bilgisinin öğretimi süreçlerinde zorlanacakları konusunda hemfikirdir.

\section{Dördüncü alt probleme ait bulgular}

Katılımcıların, YDTÖ süreçlerini yönetmede bilgi ve uygulama düzeyinde öz yeterlilik algılarına yönelik görüşleri Tablo 7'de özetlenmiştir.

Tablo 7. Katılımcıların YDTÖ Alanında Bilgi ve Uygulama Düzeyi Bağlamında Öz Yeterlilik Algılarına Yönelik Görüşleri

\begin{tabular}{|c|c|c|c|c|c|}
\hline & \multicolumn{2}{|c|}{ Türkçe Öğretmenliği } & \multicolumn{2}{|c|}{ İngilizce Öğretmenliği } & \multirow{2}{*}{ Toplam } \\
\hline & 1. grup & 2. grup & 3. grup & 4.grup & \\
\hline Yetkin hissetme & & & 6 & 6 & 12 \\
\hline Yetkin hissetmeme & 1 & 1 & & 1 & 3 \\
\hline $\begin{array}{l}\text { Mevcut bilgilerini } \\
\text { uyarlamayabileceğini düşünme }\end{array}$ & 1 & 6 & & & 7 \\
\hline $\begin{array}{l}\text { Planlama konusunda yetkin, } \\
\text { uygulamada yetersiz hissetme }\end{array}$ & & 4 & & & 4 \\
\hline $\begin{array}{l}\text { Planlama konusunda yetkin } \\
\text { hissetme }\end{array}$ & & & & 6 & 6 \\
\hline $\begin{array}{l}\text { Başlangıç seviyelerinde zorluk } \\
\text { çekeceğini, ileriki seviyelerde } \\
\text { kolaylaşacağını düşünme }\end{array}$ & 2 & & & & 2 \\
\hline $\begin{array}{l}\text { 1.grup= Türkçe Öğretmenliği } 3 . \\
\text { 2.grup= Türkçe Öğretmenliği } 4 .\end{array}$ & $\begin{array}{l}\text { ncileri } \\
\text { ncileri }\end{array}$ & $\begin{array}{l}\text { 3.gru } \\
\text { 4.gru }\end{array}$ & $\begin{array}{l}\text { lizce Öğret } \\
\text { lizce Öğret }\end{array}$ & $\begin{array}{l}\text { 3.sinif ög } \\
\text { 4.sinif ög }\end{array}$ & $\begin{array}{l}\text { ileri } \\
\text { ileri }\end{array}$ \\
\hline
\end{tabular}
gibidir;

Birinci gruptaki katılımcılardan dördüncü alt probleme yönelik elde edilen veriler aşağıldaki 
$10 ̈ 5$ kodlu 3.sınıf Türkçe öğretmeni adayı, YDTÖ alanında öğretim süreçlerinde bilgi ve uygulama düzeyinde kendini yeterli görmediğini, bununla beraber ana dili eğitimindeki bilgilerini YDTÖ alanına uyarlayabileceğini belirtmiştir. Katılımcıların bir kısmı (f:2), temel seviyede (A1, A2) eğitim süreçlerini yönetmenin daha zor olabileceğini ancak ilerleyen seviyelerde YDTÖ'nün ana dili öğretimi sürecine benzer olabileceğini varsaydıkları için kendilerini bu seviyelerde daha yetkin gördüklerini dile getirmişlerdir. gibidir;

İkinci gruptaki katılımcılardan dördüncü alt probleme ait elde edilen veriler aşağıdaki

$20 ̈ 6$ kodlu 4.sınıf Türkçe öğretmeni adayı, Türkçenin ana dili olarak öğretilmesinde öğretim süreçlerini planlama ve uygulama noktasında kendini yeterli gördügünü ancak YDTÖ süreçleri için kendini aynı yetkinlik düzeyinde hissetmediğini belirtmiştir. Bu görüşü, bazı katılımcılar da (f:3) desteklemiştir. Katılımcıların tümü (f:6), YDTÖ alanında bilgi ve uygulama becerisi boyutunda gerekli donanıma sahip olmadıklarını ifade etmiştir. Diğer taraftan bazı katılımcılar (f:3), ana dili öğretimine yönelik Türkçe öğretmenliği lisans programında edindiklerini varsaydıkları bilgi ve becerileri, YDTÖ alanına uyarlayarak yabancılara Türkçe öğretimi süreçlerini yönetmeyi deneyebileceklerini belirtmiştir. Bir başka katılımcı (2ö5), Türkçe öğretmenliği lisans programındaki eğitimi boyunca, YDTÖ alanına yönelik yeterli düzeyde ve derinlikte eğitim almadığı için bilgi ve uygulama becerisi düzeyinde yabancılara Türkçe öğretimi bağlamında kendini yetersiz gördüğünü ifade etmiştir. gibidir;

Üçüncü gruptaki katılımcılardan dördüncü alt probleme ait elde edilen veriler aşağıdaki

3.sınıf İngilizce öğretmeni adayları ortak görüş olarak (f:6), YDTÖ süreçlerinde bilgi ve uygulama becerisi düzeyinde kendilerini yeterli hissettiklerini belirtmişlerdir. Bunun nedenini yabanc1 diller eğitimi bölümü İngilizce öğretmenliği lisans programında yabancı dil öğretimine yönelik gerekli teori ve uygulama etkinliklerine derslerde yeterince yer verilmesi şeklinde açıklamışlardır. YDTÖ alanına bu bilgileri kolaylıkla uyarlayabileceklerini düşündüklerini sözlerine eklemişlerdir.

Dördüncü gruptaki katılımcılardan dördüncü alt probleme ait elde edilen veriler aşağıdaki gibidir;

4 ö6 kodlu 4.sınıf İngilizce öğretmeni adayı, İngilizce öğretmenliği lisans programında yabancı dil öğretimi alanına yönelik iyi bir eğitim alt yapısının oluştuğunu belirterek YDTÖ alanına bu birikimini transfer edebileceğini belirtmiştir. Katılımcılardan birçoğu (f:5), bu fikri onaylayarak katılımcıya (4ö6) destek vermiştir. Bir başka katılımcı (4ö3), Türkçe alan bilgisinin daha iyi olmasının öğretim süreçlerini yönetmede kolaylık sağlayacağını dile getirmiştir. Diğer bir katılımcı (4ö2), YDTÖ öğretim süreçlerinde okuma, dinleme, konuşma ve yazma becerilerinin öğretimi süreçlerinde bir şekilde başarılı olacağını ancak özellikle Türkçe dil bilgisinin öğretiminde zorlanacağını belirtmiştir. Türkçe dil bilgisi öğretimi süreçlerinde yaşayacağını varsaydığı/yaşadığı sorunun, dil bilgisine yönelik bilgi ve öğretim deneyimi eksikliğinden kaynaklandığını belirtmiştir.

Katılımcıların, YDTÖ süreçlerini yönetmede bilgi ve uygulama düzeyinde öz yeterlilik algılarına yönelik bulgular incelendiğinde, Türkçe öğretmeni adaylarının bu konuda kendilerini yeterli hissetmedikleri konusunda hemfikir oldukları görülmektedir. Buna karşın, İngilizce öğretmeni adaylarının, Türkçe öğretmeni adaylarına oranla YDTÖ süreçlerini yönetme bağlamında, bilgi ve uygulama düzeyinde, kendilerini daha yetkin hissettikleri görülmektedir.

\section{Sonuç, Tartışma ve Öneriler}

$\mathrm{Bu}$ araştırmada, Türkçe ve İngilizce öğretmenliği lisans programlarında öğrenim gören öğretmen adaylarının yabanc1 dil olarak Türkçe öğretimi (YDTÖ) alanında 
çalışacak eğiticide bulunması gereken niteliklere, yabancı dil olarak Türkçe öğretiminde alan bilgisine, öğretim yöntemleri bilgi ve becerisi boyutlarına yönelik öz yeterlilik algılarının belirlenmesi amaçlanmıştır. Öğretmen adaylarından toplanan verilerin incelenmesi sonucunda aşağıdaki sonuçlara ulaşılmıştır:

Öğretmen adaylarının; Türk kültürüne ve Türkçenin öğretileceği hedef kitlenin kültürüne hâkim olmayı, YDTÖ süreçlerinde görev alacak/alan eğiticide bulunması gereken nitelikler bağlamında ilk sırada konumlandırdıkları tespit edilmiştir. Araştırmanın bu bulgusu, Kalfa'nın (2015) bulgularıyla benzerlik göstermektedir. Nitekim Kalfa (2015) araştırmasında, YDTÖ süreçlerinde görev alan öğretmenlerin, Türkçeyi öğretirken Türk kültürünü de aktardıklarının bilincinde olduğunu ve bu bağlamda kültür ögesine önem verdiklerini vurgulamaktadır. YDTÖ süreçlerinde görev alacak eğiticide bulunması gereken nitelikler bağlamında, yabancı dil öğretim yöntemleri çerçevesinde bilgi ve uygulama becerisine sahip olma ve Türkçe alan bilgisine hâkim olma yeterliliği ikinci sırada yer almaktadır. Türkçe ve İngilizce öğretmeni adaylarının, YDTÖ süreçlerinde görev alacak eğiticide bulunması gereken nitelikleri genel olarak, Türk kültürüne ve hedef kitlenin kültürüne hâkim olmak, Türkçe alan bilgisi hâkimiyeti, yabancı dil öğretim yöntemleri bağlamında bilgi ve uygulama becerisi ile kültür hâkimiyeti olarak sıraladıkları görülmüştür. Türkçe öğretmeni adayları, alan bilgisi hâkimiyetini YDTÖ süreçlerinde görev alacak eğiticide bulunması gereken nitelikler bağlamında ilk sırada vurgularken, İngilizce öğretmen adaylarının ise hedef kitlenin kültürünü bilmenin daha önemli olduğunu düşündükleri belirlenmiştir. Özellikle Türkçe öğretmeni adayları tarafından ifade edilen alan bilgisi hakimiyeti literatürde birçok araştırmacı tarafından altı çizilen bir nitelik olarak karşımıza çıkmıştır. Alan bilgisi hakimiyeti ile ilgili olarak Brosh (1996), Cho (2006), Rishards (2010) ve Filiz ve Mete (2013) benzer bulgulara ulaşmış, yabanc1/ikinci dil öğretimi alanında görev yapacak eğiticilerin öğrettikleri dile hâkim olması gerektiği özellikle vurgulanmıştır. İngilizce öğretmen adaylarının vurguladığ 1 hedef kitlenin kültürünü bilme durumu ise araştırmanın literatürdeki diğer araştırmalardan farklı elde edilen bulgularından biri olmuştur. Literatürdeki araştırmalar (Richards, 2010; Filiz ve Mete, 2013) genel olarak kendi kültürünü bilme ve farkında olma hakkında görüşler öne sürerken bu araştırmadaki katılımcılar öğrencilerin kültürünün de bilinmesi gerektiğini ifade etmiştir.

YDTÖ süreçlerinde görev alacak eğiticilerin, İngilizce ve Türkçe öğretmenliği lisans programı mezunlarından olması gerektiği konusunda, Türkçe ve İngilizce öğretmeni adaylarının fikir birliği içinde oldukları görülmektedir. Bununla birlikte, Türkçe öğretmeni adayları yabancı dil öğretimi için gerekli yöntem bilgi ve uygulama becerisi bağlamında kendilerini yetersiz hissettiklerini ifade etmiştir. Diğer taraftan araştırma sonuçları, İngilizce öğretmen adaylarının yabanc1 dil öğretim yöntemleri bilgi ve uygulama becerisi bağlamında kendilerini yetkin, Türkçe alan bilgisi bağlamında ise yetersiz hissettiklerini ortaya koymaktadır. İngilizce öğretmenliği lisans programında yer alan YDTÖ alanına yönelik derslerin saat, çeşitlilik ve içerik bağlamındaki yetersizliğinin, İngilizce öğretmeni adaylarının kendilerini Türkçe alan bilgisinde yetkin hissetmemelerinde etkili olduğu değerlendirilmektedir. Demirel (2011), Yabancilara Türkçe Öğretimi dersine ilişkin öğrenci görüşlerini incelediği araştırmada, öğrencilerin Yabancılara Türkçe Öğretimi dersinden büyük beklenti içinde olduğunu ortaya koymakta ve ders saatlerinin yetersizliğine vurgu yapmaktadır.

Diğer taraftan, Türkçe ve İngilizce öğretmeni adaylarının tümünün YDTÖ süreçlerinde görev alacak eğiticileri eğitecek müstakil bir lisans programı açılması konusunda hemfikir oldukları görülmektedir. Araştırmanın bu bulgusuyla benzer görüşler yabancılara Türkçe öğretimi kapsamında yürütülen birç̧ok araştırmada (Mete, 2012b; Filiz ve Mete, 2013; Yıldız ve Tepeli, 2014; Barın, Çangal ve Başar,2017) dile getirilmiştir. Söz konusu araştırmalarda da benzer gereklilik vurgulanmış, devlet eliyle oluşturulacak ortak bir programın ve yeterliliklerin olması gerektiği, bu sayede yabancı dil olarak Türkçe öğretimi alanın uluslararası alandaki diğer paydaşlarıyla aynı düzeye gelebileceği ifade edilmiştir. 
Yabancı bir dil bilmenin YDTÖ süreçlerine etkisiyle ilgili bulgular incelendiğinde, katılımcıların tümü yurt dışında görev alan eğiticinin bir araç dil bilmesi gerektiği konusunda fikir birliği içindedir. Diğer taraftan Türkçe öğretmeni adayları, genel olarak Türkçe öğretimi süreçlerinde ders sırasında yabanc1/araç dil kullanılmaması gerektiğini düşünmektedir. İngilizce öğretmeni adaylarının ise Türkçenin yabancı dil olarak öğretimi süreçlerinde temel seviyede (A1, A2) yabancı/araç bir dil kullanımının yararlı olabileceği yönünde fikir birliği içinde oldukları görülmektedir. Mete (2012), yabancı dil eğiticisinin, yabancı dil edinim sürecini bizzat yaşamasının eğitici olarak öğretim süreçlerinde hedef kitlenin yaşayacağı zorlukları öngörebilmesi bağlamında faydalı olacağını belirtmektedir.

Araştırma sonuçlarına göre; Türkçe öğretmeni adayları YDTÖ süreçlerinde, yabancı dil öğretim yöntemleri bilgi ve uygulama becerisi bağlamında kendilerini yeterli hissetmediklerini ifade etmiştir. $\mathrm{Bu}$ durumun, Türkçe öğretmenliği lisans programlarında yer alan YDTÖ’ ye yönelik derslerin ders saatleri, içerikleri ve çeşitliliği bağlamındaki eksikliklerden kaynaklandığı değerlendirilmektedir. Diğer taraftan YDTÖ süreçlerinde, İngilizce öğretmeni adayları, lisans programında aldıkları eğitimi referans göstererek genel anlamda yabancı dil öğretim yöntemleri bilgi ve uygulama becerisi bağlamında kendilerini yetkin hissettiklerini ifade etmektedir.

Bu noktadan hareketle, İngilizce öğretmenliği lisans programlarındaki yabancı dil öğretim yöntemlerine yönelik öğretmenlik meslek derslerinin, İngilizce öğretmeni adaylarının yabancı dil öğretimine yönelik öğretmenlik becerilerinin gelişimine katkı sağladığı değerlendirilmektedir. İngilizce öğretmeni adayları, lisans programındaki eğitim sürecinde edindiklerini düşündükleri birikimi, YDTÖ süreçlerine de aktarabileceklerini düşünmektedir. Bu nedenle, yabancılara Türkçe öğretimi ortamlarında özellikle yabancı dil öğretim yöntemleri bilgi ve uygulama becerisi bağlamında kendilerini yetkin hissettiklerini belirtmişlerdir.

YDTÖ süreçlerinde en çok zorlanacaklarını düşündükleri dil becerilerine yönelik bulgular bağlamında, Türkçe öğretmenliği lisans programı 3. sınıf öğretmen adaylarının en çok zorlanacakları alanları; dil bilgisi öğretimi, konuşma, dinleme ve yazma becerilerinin öğretimi olarak sıraladıkları görülmektedir. Türkçe öğretmenliği lisans programı 4. sınıf öğretmen adayları YDTÖ süreçlerinde en çok zorlanacaklarını düşündükleri alanları konuşma, yazma dil becerileri ve dil bilgisi öğretimi olarak sıralamışlardır. Türkçe öğretmeni adaylarının ifade edici dil becerilerinin öğretiminde daha çok zorlanabileceklerini ifade etmeleri uzun yıllardan beri süregelen eğitim öğretim şeklinin bir yansıması olarak görülebilir. Özellikle ilk ve ortaöğretim kademelerinde geleneksel öğretim anlayışıyla eğitim almaları ve öğretim sürecinin dil bilgisi temelli sürdürülmesi ve bunun sonucunda da başta dinleme olmak üzere, konuşma ve yazma becerilerinin geliştirilmesine yönelik faaliyetlerin kısıtlı olarak sürdürmesi araștırmanın bu bulgusunun ortaya çıkmasında etkili olan etmenlerden biri olabilir. Yıldız ve Asma (2020), bu durumun sadece YDTÖ süreçlerinde sınırlı kalmadığını, anadil olarak Türkçe öğretiminde de benzer durumun ortaya çıktığını ifade etmiştir. İlgili araştırmada, Türkçe öğretim programlarını inceleyen araştırmacılar, dört temel dil becerisinin öğretimine odaklanmış, araştırma sonucunda Türkçe öğretim programının okuma becerisine yoğunlaştığını ve dinleme becerisinin dört temel dil becerisi arasında en az vurgulanan ve odaklanılan beceri olduğunu ortaya koymuşlardır.

Diğer taraftan, İngilizce öğretmenliği lisans programı 3. sınıf öğretmen adaylarının, YDTÖ süreçlerinde en çok zorlanacakları alanları; dil bilgisi ve yazma becerisi öğretimi olarak sıraladıkları görülmektedir. İngilizce öğretmenliği lisans programlarında, Türkçe alan bilgisine yönelik derslerin yer almaması, öğretmen adaylarındaki, özellikle dil bilgisi öğretimine yönelik, bu öz güven eksikliğinin sebebi olarak değerlendirilebilir. Aynı zamanda, YDTÖ süreçlerinde uygulama/staj boyutunun eksikliği, öğretmen adaylarının kendilerini yetkin hissetmemelerinin nedenlerinden biri olarak görülebilir. İngilizce öğretmenliği lisans programı 4. sınıf öğretmen adayları, YDTÖ süreçlerinde en çok zorlanacakları alanları yazma, konuşma ve dinleme becerisi öğretimi olarak 
sıralamışlardır. $\mathrm{Bu}$ durumun öğretmen adaylarının lisans alanlarıyla ilişkili olduğu söylenebilir. Nitekim İngilizce öğretmenliği lisans programındaki öğretmen adayları yabancı dil öğretimi, dil öğretim yaklaşımı, yöntemi ve teknikleri konusunda eğitim almalarına rağmen Türkçenin eğitimi konusunda çok kısıtlı olarak eğitim almaktadırlar. Bu nedenle de YDTÖ süreçlerinde bu konuda yetersiz olabileceklerini düşündükleri değerlendirilmektedir.

Türkçe öğretmeni adaylarının, ana dili öğretimi/eğitimi süreçlerini yönetmede kendilerini yetkin hissetmelerine rağmen, yabancılara Türkçe öğretimi bağlamında aynı yetkinlik düzeyinde olmadıklarını düşündükleri görülmektedir. Bu bağlamda, lisans programlarında sadece iki dönem yer alan YDTÖ’ye yönelik derslerin, ders saati, içerik ve çeşitlilik açısından öğretmen adaylarını yabancılara Türkçe öğretimi bağlamında bilgi ve uygulama becerisi boyutunda gerekli yetkinliğe ulaştırma noktasında yetersiz kaldığı söylenebilir. İngilizce öğretmeni adaylarının ise genel olarak YDTÖ süreçlerini yönetmede kendilerini yetkin hissettikleri görülmektedir. Benzer şekilde Tertemiz ve Ağıldere (2015), yabancı diller eğitimi bölümünde okuyan öğrencilerin yabancı dil öğretimine yönelik yeterlilik inanç ve görüşlerini araştırdıkları çalışmalarında; yabancı dil öğretmen adaylarının, yabancı dil öğretim süreçlerinde kullanılabilecek yöntem bilgisi ve süreçlerde karşılaşılabilecek sorunların üstesinden gelme bağlamında kendilerini yetkin hissettiklerini ortaya koymaktadır.

Ayrıca, İngilizce öğretmeni adaylarının eğitim aldıkları lisans programında edindiklerini düşündükleri bilgi birikimi ve deneyimleri, Türkçenin yabancı dil olarak öğretimi alanına uyarlayarak başarı sağlayacaklarına inandıkları görülmektedir.

Araştırmadan elde edilen bulgular ve ilgili literatürden elde edilen karşılaştırmalar sonucunda; ileri araştırmalar, program düzenleyiciler ve eğiticiler için aşağıdaki öneriler getirilmiştir:

- Tüm katılımcılar tarafından, YDTÖ'nün ayrı bir ihtisas alanı olarak değerlendirildiği görülmektedir. Diğer taraftan, Türkiye'de YDTÖ alanına yönelik lisans programları ise halen açılamamıştır (Yıldız, 2015). YDTÖ alanına özel; Türkçe alan bilgisinde, yabancı dil öğretim yöntemleri bağlamında bilgi ve uygulama becerilerinde yetkin, genel kültür boyutunda donanımlı ve vizyon sahibi öğretmenleri yetiştirecek müstakil, Türkçenin Yabancı Dil Olarak öğretimi Bölümü/Lisans Programı'nın Eğitim Fakülteleri çatısı altında bir an önce açılması için ilgili kurum ve kuruluşların ivedilikle gerekli adımları atması, sadece sıradan bir eğitim politikası hamlesi olmayacak, aynı zamanda 'ses bayrağımız Türkçe'nin yurtiçi ve yurtdışında, alana yönelik yetişmiş dil uzmanları tarafından öğretilmesini sağlayacak süreci de başlatacaktır.

- Türkçe ve İngilizce öğretmenliği lisans programlarında YDTÖ’ye yönelik uygulamalı derslerin programa dâhil edilmesi ve öğrencilere Türkçe Öğretim Merkezlerinde (TÖMER) en az iki akademik dönem devam edecek (28 hafta) staj uygulaması imkânının sağlanmasının faydalı olacağı değerlendirilmektedir.

- Öğretmen adaylarına, lisans eğitimleri sırasında YDTÖ'ye yönelik uygulama/staj imkânı (TÖMER'de staj ya da sınıf içi uygulamalar/etkinlikler dâhil) sunulmasının, öğretmen adaylarının yabancılara Türkçe öğretimi bağlamında hazırbulunuşluklarına katkı sağlayacağ 1 düşünülmektedir.

- YDTÖ bağlamında düzenlenen yabancılara Türkçe öğretimi sertifika programlarının içeriklerinin uygulama/staj, ders içeriği ve çeşitliliği boyutlarıyla zenginleştirilmesi/yeniden düzenlemesi, yabancılara Türkçe öğretimi lisans programları açılıncaya kadar kısa vadeli/geçici bir çözüm olarak değerlendirilebilir. Kana, Boylu ve Başar (2016) araştırmalarında, üniversitelerde düzenlenen yabancılara Türkçe öğretimi sertifika programlarının ders saatlerinin arttırılması ve TÖMER'lerde en az 50 saat 
uygulama (staj) boyutuna yer verilmesinin, YDTÖ bağlamında faydalı olacağını vurgulamaktadır.

- Türkçe ve İngilizce öğretmenliği lisans programlarında YDTÖ’ye yönelik uygulama boyutları zenginleştirilmiş daha fazla seçmeli ders açılabilir.

- Türkçe öğretmenliği lisans programlarına, yabancı dil öğretim yöntemlerine yönelik daha fazla teori ve uygulama odaklı dersin dâhil edilmesi sağlanabilir. Mete ve Asar (2014), Türkçe öğretmeni adaylarının YDTÖ bağlamında yöntem bilgisi derslerine ihtiyaç duyduklarını vurgulamaktadır.

- İngilizce öğretmenliği lisans programlarında yer alan yabancı dil olarak Türkçe öğretimine yönelik seçmeli derslerin, lisans programlarının tüm dönemlerine daha dengeli yayılarak program genelinde yeniden desenlenmesi/düzenlenmesi sağlanabilir.

- İngilizce öğretmenliği lisans programlarında Türkçe dil bilgisi ve dil bilgisi öğretimine yönelik derslerin yer alması sağlanabilir.

- İngilizce öğretmenliği lisans programlarında, Türkçenin yabancı dil olarak öğretimine yönelik seçmeli Türkçe alan bilgisi dersleri açılabilir.

- Yukarıda sıralanan tüm öneriler geçici çözüm önerileri olarak algılanmalı, kesinlikle Türkçenin yabancı dil olarak öğretimi bölümü/lisans programının açılmasını öteleyecek şekilde esas alınmamalıdır.

\section{Kaynakça}

Archana, S. \& Usha, R. K. (2017). Role of a teacher in English language teaching (ELT). International Journal of Educational Science and Research, 7(1), 1-4.

Barın, E., Çangal, Ö. \& Başar, U. (2017). Yabancı dil olarak Türkçe öğretimi alanında görev yapacak öğretmenlerin özel alan yeterliliklerine ilişkin bir öneri. International Journal of Language Academy, 5(7), 81-98. http://dx.doi.org/10.18033/ijla.3779

Brosh, H. (1996). Perceived characteristics of the effective language teacher. Foreign Language

Annals 29. 125-38. https://doi.org/10.1111/j.1944-9720.1996.tb02322.x

Borg, S. (2006). The distinctive characteristics of foreign language teachers. Language Teaching Research, 10(1), 3-31. https://doi.org/10.1191/13621688061r182oa

Cho, M. F. (2006). Professional competencies of foreign English teachers instructing young Children in Taiwan [Unpublished Ph. D. Thesis]. The Pennyslvania State University.

Çiftçi, M. (2011). Türkçe öğretmeni yetiştirme programı sorunu. Turkish Studies International Periodical for the Languages, Literature and History of Turkish or Turkic, 6(1), 399-405. http://dx.doi.org/10.7827/TurkishStudies.2021

Demirel, M.V. (2011). Türkçe üçüncü sınıf öğrencilerinin yabancılara Türkçe öğretimi dersine ilişkin görüşleri. Buca Eğitim Fakültesi Dergisi, 31, 128-138. https://dergipark.org.tr/tr/pub/deubefd/issue/25120/265250

Kana, F., Boylu. E. \& Başar, U. (2016). Yabancı dil olarak Türkçe öğretmeni yetiştirmenin gerekliliği ve lisans programı önerisi. Journal of Theory and Practice in Education, 12(5), 1125-1138. https://dergipark.org.tr/tr/pub/eku/issue/24404/258708 
Koehler, M. J., Mishra, P. \& Cain, W. (2013). What is Technological Pedagogical Content Knowledge (TPACK)? Journal of Education, 193(3), 13-19. https://doi.org/10.1177/002205741319300303

Mete, F. (2012). Yabancı dil olarak Türkçe öğretimine ilişkin öğretmen görüşlerinin değerlendirilmesi. Dede Korkut Türk Dili ve Edebiyatı Araştırmaları Dergisi, 1(1), 103-125. https://dergipark.org.tr/tr/pub/hunefd/issue/7791/101927

Mete, F. (2012b). Türkçeyi yabancı dil olarak öğreten ögretmenlerin özel alan yeterlikleri üzerine bir araştırma (Yayımlanmamış doktora tezi). Gazi Üniversitesi Eğitim Bilimleri Enstitüsü.

Mete, F. \& Asar, A. (2014). Üniversite programlarında yabancı dil olarak Türkçe öğretmeni alan yeterliklerinin araştırılması. Hacettepe Üniversitesi Yabancı Dil Olarak Türkçe Araştırmaları Dergisi, Yaz (1), 121-141.

Millî Eğitim Bakanlı̆̆ı (2008). Öğretmen yeterlikleri: ögretmenlik mesleği genel ve özel alan yeterlikleri. Millî Eğitim Basımevi.

Richards, J. C. (2010). Competence and Performance in Language Teaching. RELC Journal, 41(2), 101-122. https://doi.org/10.1177/0033688210372953

Saygıl1, D. \& Kana, F. (2018). Yabancı dil olarak Türkçe öğreten öğretmenlerin kültürlerarası duyarlılı̆̆1. Ana Dili Eğitimi Dergisi, 6(4), 1041-1063. https://doi.org/10.16916/aded.449622

Sysoyev, P. V. \& Evstigneev, M. N. (2014). Foreign language teachers' competency and competence in using information and communication technologies. Procedia-Social and Behavioral Sciences, 154, 82-86. https://doi.org/10.1016/j.sbspro.2015.08.037

Tertemiz, N. \& Ağıldere, S. (2015). Yabancı diller eğitimi bölümünde okuyan öğrencilerin yabancı dil öğretimine yönelik yeterlik inanç ve görüşleri. Hacettepe Üniversitesi Eğitim Fakültesi Dergisi, 30(1), 252-267. https://dspace.gazi.edu.tr/handle/20.500.12602/138697

Yıldırım, A. \& Şimşek H. (2016). Sosyal bilimlerde nitel araştırma yöntemleri. Seçkin Yayıncılık.

Yıldız, E. (2018). Yabancılara Türkçe ögretimi dersinin Türkçe ögretmeni adaylarının görüşleri bağlamında değerlendirilmesi (Yayımlanmamış yüksek lisans tezi). Tokat Gaziosmanpaşa Üniversitesi Eğitim Bilimleri Enstitüsü.

Yıldız, Ü. (2015). Yabancılara Türkçe öğretimi bağlamında program, yöntem, öğretim materyali ve değerlendirme yöntemleri sorunu: Belarus örneği. International Journal of Language Academy, 3(1), 94-112. https://doi.org/10.18033/ijla.191

Yıldız, Ü. \& Asma, B. (2020). Cumhuriyet dönemi Türkçe dersi öğretim programlarında (19242018) dil becerilerinin öğretiminde kullanılan tekniklerin incelenmesi. Kastamonu Eğitim Dergisi, 28 (3), 1168-1180. https://doi.org/10.24106/kefdergi.3642

Yıldız, Ü. \& Tepeli, Y. (2014). Yabancı dil olarak Türkçe öğretiminde öğretmen yeterlilikleri üzerine bir çalışma. International Journal of Language Academy, 2(4), 564-578. https://doi.org/10.18033/ijla.182 